\title{
Gross Morphological and Sex wise Morphometrical Studies on the Third to Fifteenth Coccygeal Vertebrae of Blue Bull (Boselaphus tragocamelus)
}

\author{
S. Sathapathy ${ }^{1 *}$, B.S. Dhote ${ }^{2}$, D. Mahanta ${ }^{2}$, S. Tamilselvan ${ }^{2}$, I. Singh ${ }^{2}$, \\ M. Mrigesh ${ }^{2}$ and S.K. Joshi ${ }^{3}$ \\ ${ }^{1}$ Department of Veterinary Anatomy \& Histology, CVSc. \& A.H., Bhubaneswar-751 003, India \\ ${ }^{2}$ Department of Veterinary Anatomy, CVASc., GBPUAT, Pantnagar - 263 145, India \\ 3 (KVK, Jharsuguda), OUAT, Bhubaneswar - 751 003, India \\ *Corresponding author
}

\begin{abstract}
A B S T R A C T
The present study was carried out on the third to fifteenth coccygeal vertebrae of six specimens of adult Blue bull (Boselaphus tragocamelus) of either sex. The $\mathrm{Cy}_{3}-\mathrm{Cy}_{6}$ presented complete arches and spinous processes. The transverse processes and cranial

Keywords

Coccygeal

vertebrae, Blue bull,

Morphology,

Morphometry

Article Info

Accepted:

04 October 2018

Available Online:

10 November 2018 non-articular processes were present in $\mathrm{Cy}_{3}-\mathrm{Cy}_{6}$ and then reduced in caudal part of the series. The transverse processes were found to be plate like that were directed downward, backward and exceeded beyond the level of the posterior articular surface of the body in $\mathrm{Cy}_{3}$. They were reduced to tubercles in were reduced to tubercles in $\mathrm{Cy}_{4}-\mathrm{Cy}_{7}$ and disappeared beyond $\mathrm{Cy}_{7}$. The neural rings were found to be complete in $\mathrm{Cy}_{3}-\mathrm{Cy}_{4}$ and then became reduced in Blue bull. The dorsal supraspinous processes were found to be thin and flat in $\mathrm{Cy}_{3}-\mathrm{Cy}_{4}$. The summits of the dorsal supraspinous processes were thick, tuberous and bifid. A foramen having $0.09 \pm 0.001 \mathrm{~cm}$ diameter was located $0.64 \pm 0.012 \mathrm{~cm}$ away from the dorsal spine in $\mathrm{Cy}_{3}$ in the Blue bull. The cranial processes were present in $\mathrm{Cy}_{3}-\mathrm{Cy}_{5}$ and they disappeared after $\mathrm{Cy}_{5}$. The caudal processes were absent. The extremities of bodies were rounded anteriorly and flattened posteriorly. The ventral spine was prominent up to $\mathrm{Cy}_{7}$ and thereafter persisted as the ventral tubercle. The fifteenth coccygeal vertebra was represented by cylindrical body with reduced processes. The Biometrical observations on different parameters of third to fifteenth coccygeal vertebrae reflected significance $(\mathrm{P}<0.05)$ differences between the sexes of this species.
\end{abstract}

\section{Introduction}

The Blue bull (Boselaphus tragocamelus) is known to be one of the biggest antelopes in Asia and is widely found in both the forests and adjoining villages with enough green grass (Sathapathy et al., 2017). Blue bull is considered sacred as per Hindu religion since Vedic period (1500-500 BC) and it is considered as religious. The Blue bull belongs to the family Bovidae and comes under the genus Boselaphus (Sathapathy et al., 2018a). The German Zoologist Scientist Peter Simon Pallas explained this species for the first time in 1766. English Zoologist Scientist Philips for the first time in 1833 narrated the binomial combination of the Blue bull. It is quite prevalent in northern and central parts of India 
especially in the foothills of Himalayas, eastern part of Pakistan and southern part of Nepal, but has vanished from Bangladesh (Sathapathy et al., 2018b). The adult male appears like ox and so called as Blue bull. They are usually seen in day times in the meadow pasture, timberland areas and agricultural land area. It prefers mostly plain or grassy plain and low hilly areas with shrubs, small bushes, scrub forests with scattered trees and does not usually found in dense forest areas, dense compact wood, etc. The Blue bulls are safeguarded beneath the IUCN since 2003 and also under safeguard of 'Schedule III' of the Indian Wildlife Protection Act, 1972 (Bagchi et al., 2004). The Blue bull is safeguarded in various parts of India such as Gir National Park (Gujarat), Kumbhalgarh Santuary (Rajasthan) and Panchamarahi Biosphere Reserve, India. The massive body of the Blue bull can be attributed to the large skeleton of the antelope. Further, the skeleton comprises of large and massive bones of axial and appendicular skeleton that not only protects the viscera, but also provides shape and support to the heavy musculature of the Blue bull (Sathapathy et al., 2018c). The present osteo-morphological study developed a baseline data on the third to fifteenth coccygeal vertebrae of adult Blue bull that would immensely help the wild life anatomists and Veterinarians in species identification and solving forensic and veterolegal cases as no previous work has been done in this field on the Blue bull.

\section{Materials and Methods}

The present study was carried out on the third to fifteenth coccygeal vertebrae of six specimens of adult Blue bulls (Boselaphus tragocamelus) of either sex. The permission for the collection of bones was acquired from the Principal Chief Conservator of Forests (PCCF), Government of Rajasthan. The bones were possessed from the Jodhpur zoo,
Rajasthan getting authentic confirmation from the Principal Chief Conservator of Forests (PCCF), Government of Rajasthan. The skeletons were taken out from the burial ground that was located in the premises of the office of the Deputy Conservator of Forest Wildlife (WL), Jodhpur. Afterwards, the specimens were processed as per standard technique given by Snedecor and Cochran (1994). The gross study was conducted under the supervision of the Zoo Authority, Jodhpur, India. The different parameters of third to fifteenth coccygeal vertebrae of Blue bull were measured and subjected to routine statistical analysis and independent samples tTest with Systat Software Inc, USA and SPSS 16.0 version software.

\section{Results and Discussion}

The skeleton of tail of Blue bull was formed by 15 to 21 in numbers of coccygeal vertebrae (Fig. 1), but Getty et al., (1930) recorded 18 to 20 coccygeal vertebrae in ox and 15 to 21 in horse, Brelend (1943) found 20 to 23 vertebrae in cat, but in the Manx cat usually 3 to 4 coccygeal vertebrae were found, Miller et al., (1964) oberved 6 to 23 coccygeal vertebrae in dog, Raghavan (1964) recorded 15 to 20 coccygeal vertebrae in ox, Smuts and Bezuidenhout (1987) studied 15 to 17 coccygeal vertebrae in camel, Yilmaz (1998) described 12 coccygeal vertebrae in porcupine, Yilmaz et al., (2000) found 18 coccygeal vertebrae in otters, Ozkan (2007) mentioned five coccygeal vertebrae in molerats and Meena (2012) observed 12 to 18 coccygeal vertebrae in chital. The $\mathrm{Cy}_{3}-\mathrm{Cy}_{6}$ presented complete arches and spinous processes. The transverse processes and cranial non-articular processes were present in $\mathrm{Cy}_{3}-\mathrm{Cy}_{6}$ and then reduced in caudal part of the series. The transverse processes were found to be plate like that were directed downward, backward and exceeded beyond the level of the posterior articular surface of the body in 
$\mathrm{Cy}_{3}$. They were reduced to tubercles in were reduced to tubercles in $\mathrm{Cy}_{4}-\mathrm{Cy}_{7}$ and disappeared beyond $\mathrm{Cy}_{7}$. The neural rings were found to be complete in $\mathrm{Cy}_{3}-\mathrm{Cy}_{4}$ and then became reduced in Blue bull. The dorsal supraspinous processes were found to be thin and flat in $\mathrm{Cy}_{3}-\mathrm{Cy}_{4}$. The summits of the dorsal supraspinous processes were thick, tuberous and bifid in Blue bull (Fig. 2 and Fig. 4). A foramen having $0.09 \pm 0.001 \mathrm{~cm}$ diameter was located $0.64 \pm 0.012 \mathrm{~cm}$ away from the dorsal spine in $\mathrm{Cy}_{3}$ in the Blue bull. The cranial processes were present in $\mathrm{Cy}_{3}-\mathrm{Cy}_{5}$ and they disappeared after $\mathrm{Cy}_{5}$. The caudal processes were absent.

The extremities of bodies were rounded anteriorly and flattened posteriorly in coccygeal vertebrae, which simulated the findings of Getty et al., (1930) in horse and ox, Raghavan (1964) in ox, Smuts and Bezuidenhout (1987) in camel and Konig and Liebich (2005) in horse. The ventral surfaces of the bodies of coccygeal vertebrae were concave in Blue bull. The ventral spine was bifid forming a groove known as sulcus vasculosus that provided the passage for the middle coccygeal artery (Fig. 3). This artery is usually approached for recording pulse rate in the Blue bull. Further, the ventral spine was prominent up to $\mathrm{Cy}_{7}$ and thereafter persisted as the ventral tubercle. The fifteenth coccygeal vertebra was represented by cylindrical body with reduced processes in Blue bull (Fig. 5).

\section{Biometrical observation}

The biometrical observations revealed characteristic differences between the sexes of the Blue bull.

\section{Third coccygeal vertebra}

Biometrical studies revealed that the average weight was found to be $19.72 \pm 0.45 \mathrm{gm}$ in adult Blue bull. Further, it was measured as
$18.85 \pm 0.20 \mathrm{gm}$ in females that was significantly lesser $(\mathrm{P}<0.05)$ than that of males, where it was found to be $20.58 \pm 0.46$ $\mathrm{gm}$. The average length of the body was found to be $4.02 \pm 0.06 \mathrm{~cm}$ in adult Blue bull. Further, it was measured as $3.90 \pm 0.06 \mathrm{~cm}$ in females that was significantly lesser $(\mathrm{P}<0.05)$ than that of males, where it was found to be $4.13 \pm 0.03$ $\mathrm{cm}$ (Table 1). Similarly, the average width of the body at the middle was found to be $1.22 \pm 0.06 \mathrm{~cm}$ in adult Blue bull. Further, it was measured as $1.10 \pm 0.06 \mathrm{~cm}$ in females that was significantly lesser $(\mathrm{P}<0.05)$ than that of males, where it was found to be $1.33 \pm 0.03 \mathrm{~cm}$.

The average cranial diameter of vertebral canal was found to be $0.15 \pm 0.01 \mathrm{~cm}$ in adult Blue bull. Further, it was measured as $0.12 \pm 0.01 \mathrm{~cm}$ in females that was significantly lesser $(\mathrm{P}<0.05)$ than that of males, where it was found to be $0.18 \pm 0.01 \mathrm{~cm}$. The average caudal diameter of vertebral canal was found to be $0.09 \pm 0.01 \mathrm{~cm}$ in adult Blue bull. Further, it was measured as $0.07 \pm 0.01 \mathrm{~cm}$ and $0.11 \pm 0.01 \mathrm{~cm}$ in females and males respectively. The average length of vertebral canal was found to be $2.83 \pm 0.03 \mathrm{~cm}$ in adult Blue bull. Further, it was measured as $2.78 \pm 0.03 \mathrm{~cm}$ and $2.88 \pm 0.02 \mathrm{~cm}$ in females and males respectively. The average distance between the vertebral canal of $\mathrm{Cy}_{3}$ and $\mathrm{Cy}_{4}$ was found to be $1.18 \pm 0.07 \mathrm{~cm}$ in adult Blue bull. Further, it was measured as $1.07 \pm 0.03$ $\mathrm{cm}$ and $1.30 \pm 0.12 \mathrm{~cm}$ in females and males respectively.

The average length of dorsal spine was found to be $0.66 \pm 0.02 \mathrm{~cm}$ in adult Blue bull. Further, it was measured as $0.62 \pm 0.02 \mathrm{~cm}$ in females that was significantly lesser $(\mathrm{P}<0.05)$ than that of males, where it was found to be $0.70 \pm 0.01$ $\mathrm{cm}$. The average height of dorsal spine at the cranial aspect was found to be $0.15 \pm 0.01 \mathrm{~cm}$ in adult Blue bull. Further, it was measured as $0.13 \pm 0.01 \mathrm{~cm}$ in females that was significantly lesser $(\mathrm{P}<0.05)$ than that of males, where it 
was found to be $0.18 \pm 0.01 \mathrm{~cm}$. Similarly, the average height of dorsal spine at the middle was found to be $0.24 \pm 0.01 \mathrm{~cm}$ in adult Blue bull.

Further, it was measured as $0.22 \pm 0.01 \mathrm{~cm}$ in females that was significantly lesser $(\mathrm{P}<0.05)$ than that of males, where it was found to be $0.27 \pm 0.01 \mathrm{~cm}$. The average height of dorsal spine at the caudal aspect was found to be $0.15 \pm 0.01 \mathrm{~cm}$ in adult Blue bull. Further, it was measured as $0.13 \pm 0.01 \mathrm{~cm}$ in females that was significantly lesser $(\mathrm{P}<0.05)$ than that of males, where it was found to be $0.17 \pm 0.01 \mathrm{~cm}$. The average thickness of dorsal spine at the cranial aspect was found to be $0.11 \pm 0.01 \mathrm{~cm}$ in adult Blue bull. Further, it was measured as $0.10 \pm 0.01 \mathrm{~cm}$ in females that was significantly lesser $(\mathrm{P}<0.05)$ than that of males, where it was found to be $0.13 \pm 0.01 \mathrm{~cm}$. Similarly, the average thickness of dorsal spine at the middle was found to be $0.18 \pm 0.01 \mathrm{~cm}$ in adult Blue bull. Further, it was measured as $0.17 \pm 0.02$ $\mathrm{cm}$ in females that was significantly lesser $(\mathrm{P}<0.05)$ than that of males, where it was found to be $0.20 \pm 0.02 \mathrm{~cm}$. The average thickness of dorsal spine at the caudal aspect was found to be $0.20 \pm 0.01 \mathrm{~cm}$ in adult Blue bull. Further, it was measured as $0.18 \pm 0.01$ $\mathrm{cm}$ and $0.22 \pm 0.01 \mathrm{~cm}$ in females and males respectively.

The average distance between the two parts of dorsal spine at the cranial aspect was found to be $0.35 \pm 0.02 \mathrm{~cm}$ in adult Blue bull. Further, it was measured as $0.32 \pm 0.01 \mathrm{~cm}$ in females that was significantly lesser $(\mathrm{P}<0.05)$ than that of males, where it was found to be $0.39 \pm 0.01 \mathrm{~cm}$. The average distance between the two parts of dorsal spine at the middle was found to be $0.24 \pm 0.01 \mathrm{~cm}$ in adult Blue bull. Further, it was measured as $0.22 \pm 0.01 \mathrm{~cm}$ and $0.25 \pm 0.01$ $\mathrm{cm}$ in females and males respectively. Similarly, the average distance between the two parts of dorsal spine at the caudal aspect was found to be $0.31 \pm 0.01 \mathrm{~cm}$ in adult Blue bull. Further, it was measured as $0.31 \pm 0.01$ $\mathrm{cm}$ and $0.32 \pm 0.01 \mathrm{~cm}$ in females and males respectively. The average length of transverse process was found to be $1.40 \pm 0.07 \mathrm{~cm}$ in adult Blue bull. Further, it was measured as $1.23 \pm 0.07 \mathrm{~cm}$ in females that was significantly lesser $(\mathrm{P}<0.05)$ than that of males, where it was found to be $1.57 \pm 0.09 \mathrm{~cm}$.

The average width of transverse process at the cranial aspect was found to be $0.93 \pm 0.04 \mathrm{~cm}$ in adult Blue bull. Further, it was measured as $0.88 \pm 0.06 \mathrm{~cm}$ and $0.99 \pm 0.05 \mathrm{~cm}$ in females and males respectively. Similarly, the average width of transverse process at the middle was found to be $0.98 \pm 0.04 \mathrm{~cm}$ in adult Blue bull. Further, it was measured as $0.95 \pm 0.06 \mathrm{~cm}$ and $1.02 \pm 0.05 \mathrm{~cm}$ in females and males respectively. The average width of transverse process at the caudal aspect was found to be $0.62 \pm 0.03 \mathrm{~cm}$ in adult Blue bull. Further, it was measured as $0.58 \pm 0.04 \mathrm{~cm}$ and $0.66 \pm 0.05$ $\mathrm{cm}$ in females and males respectively. The average distance between the transverse processes of $\mathrm{Cy}_{3}$ and $\mathrm{Cy}_{4}$ was found to be $3.25 \pm 0.04 \mathrm{~cm}$ in adult Blue bull. Further, it was measured as $3.22 \pm 0.06 \mathrm{~cm}$ and $3.29 \pm 0.05$ $\mathrm{cm}$ in females and males respectively. The average length of cranial non-articular process was found to be $1.19 \pm 0.06 \mathrm{~cm}$ in adult Blue bull. Further, it was measured as $1.05 \pm 0.04$ $\mathrm{cm}$ in females that was significantly lesser $(\mathrm{P}<0.05)$ than that of males, where it was found to be $1.33 \pm 0.07 \mathrm{~cm}$. The average width of cranial non-articular process at the cranial aspect was found to be $0.46 \pm 0.03 \mathrm{~cm}$ in adult Blue bull. Further, it was measured as $0.42 \pm 0.04 \mathrm{~cm}$ and $0.50 \pm 0.04 \mathrm{~cm}$ in females and males respectively. Similarly, the average width of cranial non-articular process at the middle was found to be $0.51 \pm 0.02 \mathrm{~cm}$ in adult Blue bull. Further, it was measured as $0.48 \pm 0.03 \mathrm{~cm}$ and $0.54 \pm 0.03 \mathrm{~cm}$ in females and males respectively. The average width of cranial non-articular process at the caudal aspect was found to be $0.43 \pm 0.01 \mathrm{~cm}$ in adult 
Blue bull. Further, it was measured as $0.40 \pm 0.01 \mathrm{~cm}$ in females that was significantly lesser $(\mathrm{P}<0.05)$ than that of males, where it was found to be $0.46 \pm 0.01 \mathrm{~cm}$.

The average minimum distance between the two cranial non-articular processes was found to be $1.32 \pm 0.01 \mathrm{~cm}$ in adult Blue bull. Further, it was measured as $1.30 \pm 0.01 \mathrm{~cm}$ in females that was significantly lesser $(\mathrm{P}<0.05)$ than that of males, where it was found to be $1.35 \pm 0.01$ $\mathrm{cm}$. The average distance between the cranial non-articular process and transverse process was found to be $1.41 \pm 0.03 \mathrm{~cm}$ in adult Blue bull. Further, it was measured as $1.39 \pm 0.04$ $\mathrm{cm}$ and $1.44 \pm 0.03 \mathrm{~cm}$ in females and males respectively.

The average distance between the cranial nonarticular processes of $\mathrm{Cy}_{3}$ and $\mathrm{Cy}_{4}$ was found to be $3.30 \pm 0.06 \mathrm{~cm}$ in adult Blue bull. Further, it was measured as $3.28 \pm 0.09 \mathrm{~cm}$ and $3.33 \pm 0.09 \mathrm{~cm}$ in females and males respectively. The average length of ventral spine was found to be $1.37 \pm 0.05 \mathrm{~cm}$ in adult Blue bull. Further, it was measured as $1.34 \pm 0.07 \mathrm{~cm}$ and $1.39 \pm 0.07 \mathrm{~cm}$ in females and males respectively. Similarly, the average height of ventral spine at the cranial aspect was found to be $0.41 \pm 0.02 \mathrm{~cm}$ in adult Blue bull. Further, it was measured as $0.38 \pm 0.02$ $\mathrm{cm}$ and $0.43 \pm 0.02 \mathrm{~cm}$ in females and males respectively. The average height of ventral spine at the middle was found to be $0.46 \pm 0.01$ $\mathrm{cm}$ in adult Blue bull. Further, it was measured as $0.44 \pm 0.01 \mathrm{~cm}$ in females that was significantly lesser $(\mathrm{P}<0.05)$ than that of males, where it was found to be $0.48 \pm 0.01 \mathrm{~cm}$. Similarly, the average height of ventral spine at the caudal aspect was found to be $0.43 \pm 0.01$ $\mathrm{cm}$ in adult Blue bull. Further, it was measured as $0.41 \pm 0.01 \mathrm{~cm}$ in females that was significantly lesser $(\mathrm{P}<0.05)$ than that of males, where it was found to be $0.46 \pm 0.01 \mathrm{~cm}$. The average distance between the ventral spines of $\mathrm{Cy}_{3}$ and $\mathrm{Cy}_{4}$ was found to be
$2.86 \pm 0.03 \mathrm{~cm}$ in adult Blue bull. Further, it was measured as $2.78 \pm 0.02 \mathrm{~cm}$ in females that was significantly lesser $(\mathrm{P}<0.05)$ than that of males, where it was found to be $2.95 \pm 0.02 \mathrm{~cm}$.

The average length of sulcus vasculosus was found to be $1.34 \pm 0.02 \mathrm{~cm}$ in adult Blue bull. Further, it was measured as $1.30 \pm 0.01 \mathrm{~cm}$ in females that was significantly lesser $(\mathrm{P}<0.05)$ than that of males, where it was found to be $1.38 \pm 0.02 \mathrm{~cm}$. The average width of sulcus vasculosus at the cranial aspect was found to be $0.22 \pm 0.02 \mathrm{~cm}$ in adult Blue bull. Further, it was measured as $0.20 \pm 0.01 \mathrm{~cm}$ and $0.24 \pm 0.03$ $\mathrm{cm}$ in females and males respectively. Similarly, the average width of sulcus vasculosus at the middle was found to be $0.17 \pm 0.01 \mathrm{~cm}$ in adult Blue bull. Further, it was measured as $0.15 \pm 0.01 \mathrm{~cm}$ and $0.18 \pm 0.01$ $\mathrm{cm}$ in females and males respectively. The average width of sulcus vasculosus at the caudal aspect was found to be $0.14 \pm 0.01 \mathrm{~cm}$ in adult Blue bull. Further, it was measured as $0.11 \pm 0.01 \mathrm{~cm}$ and $0.17 \pm 0.02 \mathrm{~cm}$ in females and males respectively. The average distance between the sulcus vasculosus of $\mathrm{Cy}_{3}$ and $\mathrm{Cy}_{4}$ was found to be $3.27 \pm 0.06 \mathrm{~cm}$ in adult Blue bull. Further, it was measured as $3.17 \pm 0.09$ $\mathrm{cm}$ and $3.37 \pm 0.03 \mathrm{~cm}$ in females and males respectively.

\section{Fourth to fifteenth coccygeal vertebrae}

Biometrical observations revealed that the average weight of $\mathrm{Cy}_{4}$ was found to be $8.47 \pm 0.29 \mathrm{gm}$ in adult Blue bull. Further, it was measured as $7.95 \pm 0.04 \mathrm{gm}$ and $8.98 \pm 0.39$ $\mathrm{gm}$ in females and males respectively. The average weight of $\mathrm{Cy}_{5}$ was found to be $6.81 \pm 0.09 \mathrm{gm}$ in adult Blue bull. Further, it was measured as $6.66 \pm 0.05 \mathrm{gm}$ and $6.96 \pm 0.12$ gm in females and males respectively. Similarly, the average weight of $\mathrm{Cy}_{6}$ was found to be $5.31 \pm 0.06 \mathrm{gm}$ in adult Blue bull. Further, it was measured as 5.23 \pm 0.04 gm and $5.39 \pm 0.09 \mathrm{gm}$ in females and males 
respectively. The average weight of $\mathrm{Cy}_{7}$ was found to be $4.15 \pm 0.08 \mathrm{gm}$ in adult Blue bull. Further, it was measured as $4.00 \pm 0.07 \mathrm{gm}$ in females that was significantly lesser $(\mathrm{P}<0.05)$ than that of males, where it was found to be $4.30 \pm 0.05 \mathrm{gm}$. The average weight of $\mathrm{Cy}_{8}$ was found to be $3.87 \pm 0.05 \mathrm{gm}$ in adult Blue bull. Further, it was measured as $3.78 \pm 0.03 \mathrm{gm}$ in females that was significantly lesser $(\mathrm{P}<0.05)$ than that of males, where it was found to be $3.95 \pm 0.05 \mathrm{gm}$. Similarly, the average weight of $\mathrm{Cy}_{9}$ was found to be $3.27 \pm 0.06$ gm in adult Blue bull.

Further, it was measured as $3.16 \pm 0.03 \mathrm{gm}$ in females that was significantly lesser $(\mathrm{P}<0.05)$ than that of males, where it was found to be $3.38 \pm 0.06 \mathrm{gm}$. The average weight of $\mathrm{Cy}_{10}$ was found to be $3.19 \pm 0.06 \mathrm{gm}$ in adult Blue bull. Further, it was measured as $3.09 \pm 0.02$ gm in females that was significantly lesser $(\mathrm{P}<0.05)$ than that of males, where it was found to be $3.29 \pm 0.07 \mathrm{gm}$. Similarly, the average weight of $\mathrm{Cy}_{11}$ was found to be $3.10 \pm 0.05 \mathrm{gm}$ in adult Blue bull. Further, it was measured as $3.01 \pm 0.01 \mathrm{gm}$ in females that was significantly lesser $(\mathrm{P}<0.05)$ than that of males, where it was found to be $3.18 \pm 0.06 \mathrm{gm}$.

The average weight of $\mathrm{Cy}_{12}$ was found to be $2.89 \pm 0.04 \mathrm{gm}$ in adult Blue bull. Further, it was measured as $2.81 \pm 0.01 \mathrm{gm}$ in females that was significantly lesser $(\mathrm{P}<0.05)$ than that of males, where it was found to be $2.96 \pm 0.03 \mathrm{gm}$. The average weight of $\mathrm{Cy}_{13}$ was found to be $2.81 \pm 0.03 \mathrm{gm}$ in adult Blue bull. Further, it was measured as $2.75 \pm 0.02 \mathrm{gm}$ and $2.87 \pm 0.04$ gm in females and males respectively.

The average weight of $\mathrm{Cy}_{14}$ was found to be $2.28 \pm 0.03 \mathrm{gm}$ in adult Blue bull. Further, it was measured as $2.22 \pm 0.02 \mathrm{gm}$ in females that was significantly lesser $(\mathrm{P}<0.05)$ than that of males, where it was found to be $2.34 \pm 0.02 \mathrm{gm}$. Similarly, the average weight of $\mathrm{Cy}_{15}$ was found to be $1.98 \pm 0.05 \mathrm{gm}$ in adult Blue bull.
Further, it was measured as $1.88 \pm 0.03 \mathrm{gm}$ in females that was significantly lesser $(\mathrm{P}<0.05)$ than that of males, where it was found to be $2.08 \pm 0.04 \mathrm{gm}$.

The average length of the body of $\mathrm{Cy}_{4}$ was found to be $3.33 \pm 0.09 \mathrm{~cm}$ in adult Blue bull. Further, it was measured as $3.17 \pm 0.09 \mathrm{~cm}$ in females that was significantly lesser $(\mathrm{P}<0.05)$ than that of males, where it was found to be $3.50 \pm 0.06 \mathrm{~cm}$. Similarly, the average length of the body of $\mathrm{Cy}_{5}$ was found to be $3.70 \pm 0.07 \mathrm{~cm}$ in adult Blue bull. Further, it was measured as $3.57 \pm 0.09 \mathrm{~cm}$ in females that was significantly lesser $(\mathrm{P}<0.05)$ than that of males, where it was found to be $3.83 \pm 0.03 \mathrm{~cm}$. The average length of the body of $\mathrm{Cy}_{6}$ was found to be $3.52 \pm 0.05 \mathrm{~cm}$ in adult Blue bull. Further, it was measured as $3.43 \pm 0.03 \mathrm{~cm}$ and $3.60 \pm 0.06$ $\mathrm{cm}$ in females and males respectively. The average length of the body of $\mathrm{Cy}_{7}$ was found to be $3.12 \pm 0.07 \mathrm{~cm}$ in adult Blue bull. Further, it was measured as $3.00 \pm 0.06 \mathrm{~cm}$ and $3.23 \pm 0.09 \mathrm{~cm}$ in females and males respectively. Similarly, the average length of the body of $\mathrm{Cy}_{8}$ was found to be $3.30 \pm 0.09 \mathrm{~cm}$ in adult Blue bull.

Further, it was measured as $3.17 \pm 0.12 \mathrm{~cm}$ and $3.43 \pm 0.09 \mathrm{~cm}$ in females and males respectively. The average length of the body of $\mathrm{Cy}_{9}$ was found to be $3.35 \pm 0.08 \mathrm{~cm}$ in adult Blue bull. Further, it was measured as $3.20 \pm 0.06 \mathrm{~cm}$ in females that was significantly lesser $(\mathrm{P}<0.05)$ than that of males, where it was found to be $3.50 \pm 0.06 \mathrm{~cm}$. The average length of the body of $\mathrm{Cy}_{10}$ was found to be $3.03 \pm 0.07 \mathrm{~cm}$ in adult Blue bull.

Further, it was measured as $2.93 \pm 0.09 \mathrm{~cm}$ and $3.13 \pm 0.09 \mathrm{~cm}$ in females and males respectively. Similarly, the average length of the body of $\mathrm{Cy}_{11}$ was found to be $2.78 \pm 0.07$ $\mathrm{cm}$ in adult Blue bull. Further, it was measured as $2.67 \pm 0.09 \mathrm{~cm}$ and $2.90 \pm 0.06 \mathrm{~cm}$ in females and males respectively. 
Table.1 Measurements of third coccygeal vertebra of Blue bull in $\mathrm{cm}$

\begin{tabular}{|c|c|c|c|c|c|c|c|c|}
\hline \multicolumn{3}{|c|}{ Parameters } & Range & Mean & SD & SE & Fem & \\
\hline \multirow[t]{2}{*}{ Body } & \multicolumn{2}{|l|}{ Length } & $3.8-4.2$ & 4.02 & 0.15 & 0.06 & $3.90 * \pm 0.06$ & $4.13 \pm 0.03$ \\
\hline & \multicolumn{2}{|c|}{ Width at the middle } & $1.0-1.4$ & 1.22 & 0.15 & 0.06 & $1.10 * \pm 0.06$ & $1.33 \pm 0.03$ \\
\hline \multirow{7}{*}{$\begin{array}{l}\text { Dorsal } \\
\text { spine }\end{array}$} & \multicolumn{2}{|c|}{ Length } & $0.57-0.75$ & 0.66 & 0.05 & 0.02 & $0.62 * \pm 0.02$ & $0.70 \pm 0.01$ \\
\hline & \multirow[t]{3}{*}{ Height } & Cranial & $0.09-0.20$ & 0.15 & 0.03 & 0.01 & $0.13^{*} \pm 0.01$ & $0.18 \pm 0.01$ \\
\hline & & Middle & $0.18-0.29$ & 0.24 & 0.03 & 0.01 & $0.22 * \pm 0.01$ & $0.27 \pm 0.01$ \\
\hline & & Caudal & $0.11-0.20$ & 0.15 & 0.03 & 0.01 & $0.13 * \pm 0.01$ & $0.17 \pm 0.01$ \\
\hline & \multirow[t]{3}{*}{ Thickness } & Cranial & $0.09-0.15$ & 0.11 & 0.02 & 0.01 & $0.10 * \pm 0.01$ & $0.13 \pm 0.01$ \\
\hline & & Middle & $0.11-0.26$ & 0.18 & 0.05 & 0.01 & $0.17 \pm 0.02$ & $0.20 \pm 0.02$ \\
\hline & & Caudal & $0.13-0.26$ & 0.20 & 0.04 & 0.01 & $0.18 \pm 0.01$ & $0.22 \pm 0.01$ \\
\hline \multirow{4}{*}{$\begin{array}{l}\text { Transverse } \\
\text { process }\end{array}$} & \multicolumn{2}{|c|}{ Length } & $1.0-1.9$ & 1.40 & 0.25 & 0.07 & $1.23 * \pm 0.07$ & $1.57 \pm 0.09$ \\
\hline & \multirow[t]{3}{*}{ Width } & Cranial & $0.70-1.11$ & 0.93 & 0.13 & 0.04 & $0.88 \pm 0.06$ & $0.99 \pm 0.05$ \\
\hline & & Middle & $0.79-1.16$ & 0.98 & 0.13 & 0.04 & $0.95 \pm 0.06$ & $1.02 \pm 0.05$ \\
\hline & & Caudal & $0.46-0.81$ & 0.62 & 0.12 & 0.03 & $0.58 \pm 0.04$ & $0.66 \pm 0.05$ \\
\hline \multirow{4}{*}{$\begin{array}{l}\text { Cranial } \\
\text { non- } \\
\text { articular } \\
\text { process }\end{array}$} & \multicolumn{2}{|c|}{ Length } & $0.9-1.5$ & 1.19 & 0.20 & 0.06 & $1.05 * \pm 0.04$ & $1.33 \pm 0.07$ \\
\hline & \multirow[t]{3}{*}{ Width } & Cranial & $0.30-0.62$ & 0.46 & 0.10 & 0.03 & $0.42 \pm 0.04$ & $0.50 \pm 0.04$ \\
\hline & & Middle & $0.40-0.64$ & 0.51 & 0.08 & 0.02 & $0.48 \pm 0.03$ & $0.54 \pm 0.03$ \\
\hline & & Caudal & $0.37-0.49$ & 0.43 & 0.04 & 0.01 & $0.40 * \pm 0.01$ & $0.46 \pm 0.01$ \\
\hline \multirow{4}{*}{$\begin{array}{l}\text { Ventral } \\
\text { spine }\end{array}$} & \multicolumn{2}{|l|}{ Length } & $1.18-1.61$ & 1.37 & 0.16 & 0.05 & $1.34 \pm 0.07$ & $1.39 \pm 0.07$ \\
\hline & \multirow[t]{3}{*}{ Height } & Cranial & $0.32-0.51$ & 0.41 & 0.06 & 0.02 & $0.38 \pm 0.02$ & $0.43 \pm 0.02$ \\
\hline & & Middle & $0.41-0.50$ & 0.46 & 0.03 & 0.01 & $0.44 * \pm 0.01$ & $0.48 \pm 0.01$ \\
\hline & & Caudal & $0.37-0.48$ & 0.43 & 0.03 & 0.01 & $0.41 * \pm 0.01$ & $0.46 \pm 0.01$ \\
\hline \multicolumn{3}{|c|}{$\begin{array}{l}\text { Distance between cranial non- } \\
\text { articular process and transverse } \\
\text { process }\end{array}$} & $1.29-1.55$ & 1.41 & 0.09 & 0.03 & $1.39 \pm 0.04$ & $1.44 \pm 0.03$ \\
\hline \multirow{4}{*}{$\begin{array}{l}\text { Sulcus } \\
\text { vasculosus }\end{array}$} & \multicolumn{2}{|c|}{ Length } & $1.28-1.41$ & 1.34 & 0.05 & 0.02 & $1.30 * \pm 0.01$ & $1.38 \pm 0.02$ \\
\hline & \multirow[t]{3}{*}{ Width } & Cranial & $0.17-0.29$ & 0.22 & 0.04 & 0.02 & $0.20 \pm 0.01$ & $0.24 \pm 0.03$ \\
\hline & & Middle & $0.13-0.19$ & 0.17 & 0.02 & 0.01 & $0.15 \pm 0.01$ & $0.18 \pm 0.01$ \\
\hline & & Caudal & $0.10-0.20$ & 0.14 & 0.04 & 0.01 & $0.11 \pm 0.01$ & $0.17 \pm 0.02$ \\
\hline \multirow{2}{*}{\multicolumn{2}{|c|}{$\begin{array}{l}\text { Diameter of vertebral } \\
\text { canal }\end{array}$}} & Cranial & $0.10-0.19$ & 0.15 & 0.03 & 0.01 & $0.12 * \pm 0.01$ & $0.18 \pm 0.01$ \\
\hline & & Caudal & $0.05-0.13$ & 0.09 & 0.03 & 0.01 & $0.07 \pm 0.01$ & $0.11 \pm 0.01$ \\
\hline \multirow{3}{*}{\multicolumn{2}{|c|}{$\begin{array}{l}\text { Distance between two } \\
\text { parts of dorsal spine }\end{array}$}} & Cranial & $0.30-0.40$ & 0.35 & 0.04 & 0.02 & $0.32 * \pm 0.01$ & $0.39 \pm 0.01$ \\
\hline & & Middle & $0.21-0.27$ & 0.24 & 0.02 & 0.01 & $0.22 \pm 0.01$ & $0.25 \pm 0.01$ \\
\hline & & Caudal & $0.29-0.34$ & 0.31 & 0.02 & 0.01 & $0.31 \pm 0.01$ & $0.32 \pm 0.01$ \\
\hline \multicolumn{3}{|c|}{ Length of vertebral canal } & $2.72-2.92$ & 2.83 & 0.07 & 0.03 & $2.78 \pm 0.03$ & $2.88 \pm 0.02$ \\
\hline \multicolumn{3}{|c|}{$\begin{array}{l}\text { Minimum distance between two } \\
\text { cranial non-articular processes }\end{array}$} & $1.28-1.36$ & 1.32 & 0.03 & 0.01 & $1.30 * \pm 0.01$ & $1.35 \pm 0.01$ \\
\hline
\end{tabular}

Values bearing superscript $(*)$ differ significantly in column $\mathrm{P}<0.05$ 
Table.2 Different measurements of coccygeal vertebra of Blue bull in $\mathrm{cm}$

\begin{tabular}{|c|c|c|c|c|c|c|c|c|}
\hline \multicolumn{3}{|c|}{$\begin{array}{l}\text { Parameters } \\
\end{array}$} & \multirow{2}{*}{$\begin{array}{l}\text { Range } \\
\text { 3.0-3.6 }\end{array}$} & \multirow{2}{*}{$\begin{array}{l}\text { Mean } \\
3.33\end{array}$} & \multirow{2}{*}{$\begin{array}{l}\text { SD } \\
0.22\end{array}$} & \multirow{2}{*}{$\begin{array}{l}\text { SE } \\
0.09\end{array}$} & \multirow{2}{*}{$\begin{array}{c}\text { Female } \\
(\text { Mean } \pm \text { SE) } \\
3.17 * \pm 0.09\end{array}$} & \multirow{2}{*}{$\begin{array}{c}\text { Male } \\
(\text { Mean } \pm \text { SE) } \\
3.50 \pm 0.06\end{array}$} \\
\hline \multirow{12}{*}{\multicolumn{2}{|c|}{ Length of body }} & $\mathrm{Cy}_{4}$ & & & & & & \\
\hline & & $\mathrm{Cy}_{5}$ & 3.4-3.9 & 3.70 & 0.18 & 0.07 & $3.57 * \pm 0.09$ & $3.83 \pm 0.03$ \\
\hline & & $\mathrm{Cy}_{6}$ & 3.4-3.7 & 3.52 & 0.12 & 0.05 & $3.43 \pm 0.03$ & $3.60 \pm 0.06$ \\
\hline & & $\mathrm{Cy}_{7}$ & $2.9-3.4$ & 3.12 & 0.17 & 0.07 & $3.00 \pm 0.06$ & $3.23 \pm 0.09$ \\
\hline & & $\mathrm{Cy}_{8}$ & 3.0-3.6 & 3.30 & 0.22 & 0.09 & $3.17 \pm 0.12$ & $3.43 \pm 0.09$ \\
\hline & & $\mathrm{Cy}_{9}$ & 3.1-3.6 & 3.35 & 0.19 & 0.08 & $3.20 * \pm 0.06$ & $3.50 \pm 0.06$ \\
\hline & & $\mathrm{Cy}_{10}$ & $2.8-3.3$ & 3.03 & 0.18 & 0.07 & $2.93 \pm 0.09$ & $3.13 \pm 0.09$ \\
\hline & & $\mathrm{Cy}_{11}$ & $2.5-3.0$ & 2.78 & 0.17 & 0.07 & $2.67 \pm 0.09$ & $2.90 \pm 0.06$ \\
\hline & & $\mathrm{Cy}_{12}$ & $2.4-2.8$ & 2.62 & 0.15 & 0.06 & $2.57 \pm 0.09$ & $2.67 \pm 0.09$ \\
\hline & & $\mathrm{Cy}_{13}$ & $1.9-2.2$ & 2.10 & 0.18 & 0.07 & $1.97 * \pm 0.03$ & $2.23 \pm 0.09$ \\
\hline & & $\mathrm{Cy}_{14}$ & $1.3-1.8$ & 1.60 & 0.18 & 0.07 & $1.47 * \pm 0.09$ & $1.73 \pm 0.03$ \\
\hline & & $\mathrm{Cy}_{15}$ & $1.0-1.4$ & 1.20 & 0.14 & 0.06 & $1.10 \pm 0.06$ & $1.30 \pm 0.06$ \\
\hline \multirow{4}{*}{\multicolumn{2}{|c|}{ Length of transverse process }} & $\mathrm{Cy}_{4}$ & $0.67-0.92$ & 0.81 & 0.07 & 0.02 & $0.75 * \pm 0.02$ & $0.86 \pm 0.02$ \\
\hline & & $\mathrm{Cy}_{5}$ & $0.51-0.79$ & 0.67 & 0.09 & 0.02 & $0.63 \pm 0.03$ & $0.71 \pm 0.03$ \\
\hline & & $\mathrm{Cy}_{6}$ & $0.64-0.94$ & 0.84 & 0.09 & 0.03 & $0.79 \pm 0.04$ & $0.89 \pm 0.02$ \\
\hline & & $\mathrm{Cy}_{7}$ & $0.40-0.60$ & 0.51 & 0.06 & 0.02 & $0.47 * \pm 0.02$ & $0.55 \pm 0.01$ \\
\hline \multirow{6}{*}{\multicolumn{2}{|c|}{$\begin{array}{l}\text { Distance between transverse } \\
\text { processes of adjacent vertebrae }\end{array}$}} & $\mathrm{Cy}_{1}-\mathrm{Cy}_{2}$ & $3.18-3.71$ & 3.47 & 0.18 & 0.05 & $3.39 \pm 0.08$ & $3.55 \pm 0.06$ \\
\hline & & $\mathrm{Cy}_{2}-\mathrm{Cy}_{3}$ & $3.08-3.28$ & 3.17 & 0.06 & 0.02 & $3.14 \pm 0.02$ & $3.20 \pm 0.03$ \\
\hline & & $\mathrm{Cy}_{3}-\mathrm{Cy}_{4}$ & $3.02-3.42$ & 3.25 & 0.14 & 0.04 & $3.22 \pm 0.06$ & $3.29 \pm 0.05$ \\
\hline & & $\mathrm{Cy}_{4}-\mathrm{Cy}_{5}$ & $3.28-3.62$ & 3.48 & 0.11 & 0.03 & $3.43 \pm 0.05$ & $3.53 \pm 0.03$ \\
\hline & & $\mathrm{Cy}_{5}-\mathrm{Cy}_{6}$ & $3.09-3.56$ & 3.31 & 0.19 & 0.05 & $3.27 \pm 0.08$ & $3.34 \pm 0.08$ \\
\hline & & $\mathrm{Cy}_{6}-\mathrm{Cy}_{7}$ & $2.56-3.14$ & 2.84 & 0.27 & 0.08 & $2.81 \pm 0.12$ & $2.87 \pm 0.11$ \\
\hline \multirow{4}{*}{\multicolumn{2}{|c|}{$\begin{array}{l}\text { Distance between cranial non- } \\
\text { articular processes of adjacent } \\
\text { vertebrae }\end{array}$}} & $\mathrm{Cy}_{1}-\mathrm{Cy}_{2}$ & $3.19-3.50$ & 3.36 & 0.10 & 0.03 & $3.31 \pm 0.04$ & $3.41 \pm 0.04$ \\
\hline & & $\mathrm{Cy}_{2}-\mathrm{Cy}_{3}$ & $3.19-3.40$ & 3.29 & 0.06 & 0.02 & $3.25^{*} \pm 0.02$ & $3.33 \pm 0.02$ \\
\hline & & $\mathrm{Cy}_{3}-\mathrm{Cy}_{4}$ & $3.05-3.56$ & 3.30 & 0.21 & 0.06 & $3.28 \pm 0.09$ & $3.33 \pm 0.09$ \\
\hline & & $\mathrm{Cy}_{4}-\mathrm{Cy}_{5}$ & $2.99-3.35$ & 3.17 & 0.13 & 0.04 & $3.14 \pm 0.05$ & $3.20 \pm 0.06$ \\
\hline \multirow{6}{*}{\multicolumn{2}{|c|}{$\begin{array}{l}\text { Distance between sulcus } \\
\text { vasculosus of adjacent } \\
\text { vertebrae }\end{array}$}} & $\mathrm{Cy}_{1}-\mathrm{Cy}_{2}$ & $2.2-2.6$ & 2.45 & 0.14 & 0.06 & $2.37 \pm 0.09$ & $2.53 \pm 0.03$ \\
\hline & & $\mathrm{Cy}_{2}-\mathrm{Cy}_{3}$ & $2.6-2.8$ & 2.72 & 0.08 & 0.03 & $2.67 \pm 0.03$ & $2.77 \pm 0.03$ \\
\hline & & $\mathrm{Cy}_{3}-\mathrm{Cy}_{4}$ & $3.0-3.4$ & 3.27 & 0.15 & 0.06 & $3.17 \pm 0.09$ & $3.37 \pm 0.03$ \\
\hline & & $\mathrm{Cy}_{4}-\mathrm{Cy}_{5}$ & $2.9-3.4$ & 3.10 & 0.18 & 0.07 & $3.00 \pm 0.06$ & $3.20 \pm 0.12$ \\
\hline & & $\mathrm{Cy}_{5}-\mathrm{Cy}_{6}$ & $2.9-3.3$ & 3.10 & 0.14 & 0.06 & $3.00 \pm 0.06$ & $3.20 \pm 0.06$ \\
\hline & & $\mathrm{Cy}_{6}-\mathrm{Cy}_{7}$ & $2.8-3.3$ & 3.05 & 0.16 & 0.07 & $2.97 \pm 0.09$ & $3.13 \pm 0.09$ \\
\hline \multirow{6}{*}{\multicolumn{2}{|c|}{$\begin{array}{l}\text { Distance between ventral spines } \\
\text { of adjacent vertebrae }\end{array}$}} & $\mathrm{Cy}_{1}-\mathrm{Cy}_{2}$ & $2.09-2.45$ & 2.27 & 0.13 & 0.04 & $2.24 \pm 0.06$ & $2.30 \pm 0.05$ \\
\hline & & $\mathrm{Cy}_{2}-\mathrm{Cy}_{3}$ & $2.48-3.22$ & 2.86 & 0.32 & 0.09 & $2.82 \pm 0.13$ & $2.90 \pm 0.14$ \\
\hline & & $\mathrm{Cy}_{3}-\mathrm{Cy}_{4}$ & $2.70-3.01$ & 2.86 & 0.10 & 0.03 & $2.78 * \pm 0.02$ & $2.95 \pm 0.02$ \\
\hline & & $\mathrm{Cy}_{4}-\mathrm{Cy}_{5}$ & $3.08-3.28$ & 3.17 & 0.06 & 0.02 & $3.14 \pm 0.02$ & $3.21 \pm 0.02$ \\
\hline & & $\mathrm{Cy}_{5}-\mathrm{Cy}_{6}$ & $3.11-3.33$ & 3.21 & 0.08 & 0.02 & $3.17 \pm 0.03$ & $3.25 \pm 0.03$ \\
\hline & & $\mathrm{Cy}_{6}-\mathrm{Cy}_{7}$ & $3.07-3.42$ & 3.21 & 0.13 & 0.04 & $3.16 \pm 0.04$ & $3.26 \pm 0.05$ \\
\hline \multirow{3}{*}{\multicolumn{2}{|c|}{$\begin{array}{l}\text { Distance between vertebral } \\
\text { canal of adjacent vertebrae }\end{array}$}} & $\mathrm{Cy}_{1}-\mathrm{Cy}_{2}$ & $1.8-2.3$ & 2.02 & 0.17 & 0.07 & $1.90 \pm 0.06$ & $2.13 \pm 0.09$ \\
\hline & & $\mathrm{Cy}_{2}-\mathrm{Cy}_{3}$ & $1.8-2.4$ & 2.05 & 0.23 & 0.10 & $1.87 * \pm 0.07$ & $2.23 \pm 0.09$ \\
\hline & & $\mathrm{Cy}_{3}-\mathrm{Cy}_{4}$ & $1.0-1.5$ & 1.18 & 0.18 & 0.07 & $1.07 \pm 0.03$ & $1.30 \pm 0.12$ \\
\hline \multirow{4}{*}{$\begin{array}{l}\text { Sulcus } \\
\text { vasculosus }\end{array}$} & \multirow[t]{4}{*}{ Length } & $\mathrm{Cy}_{4}$ & $0.64-0.91$ & 0.79 & 0.09 & 0.04 & $0.73 \pm 0.05$ & $0.85 \pm 0.04$ \\
\hline & & $\mathrm{Cy}_{5}$ & $0.58-0.72$ & 0.66 & 0.05 & 0.02 & $0.62 * \pm 0.02$ & $0.69 \pm 0.01$ \\
\hline & & $\mathrm{Cy}_{6}$ & $0.99-1.11$ & 1.06 & 0.04 & 0.02 & $1.03 * \pm 0.02$ & $1.09 \pm 0.01$ \\
\hline & & $\mathrm{Cy}_{7}$ & $0.59-0.69$ & 0.64 & 0.03 & 0.01 & $0.62 \pm 0.02$ & $0.65 \pm 0.02$ \\
\hline
\end{tabular}




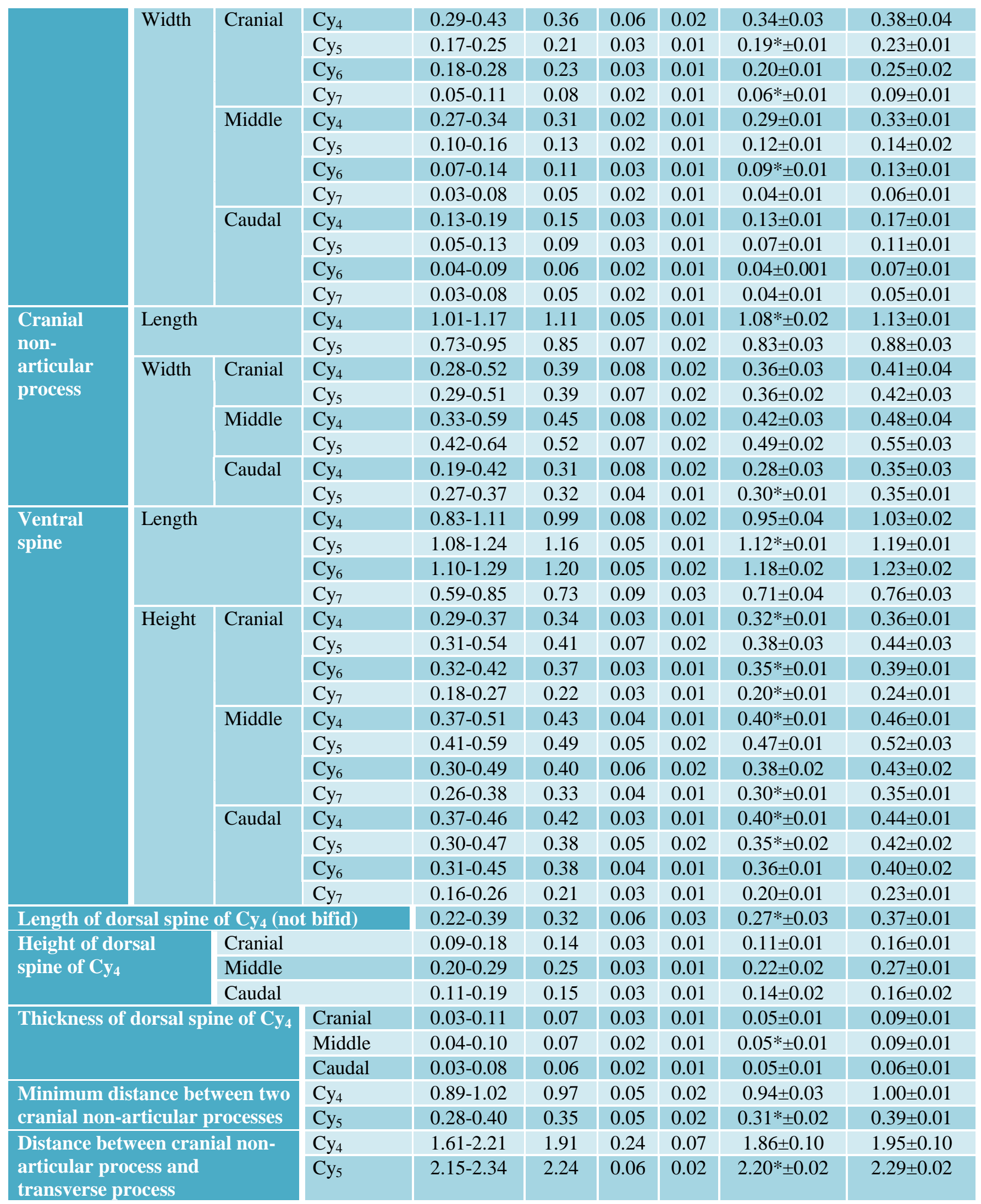

Values bearing superscript $\left(^{*}\right)$ differ significantly in column $\mathrm{P}<0.05$ 
Fig.1 Ventral view of coccygeal vertebrae $\left(\mathrm{Cy}_{1}-\mathrm{Cy}_{15}\right)$ of adult male Blue bull (Boselaphus tragocamelus)

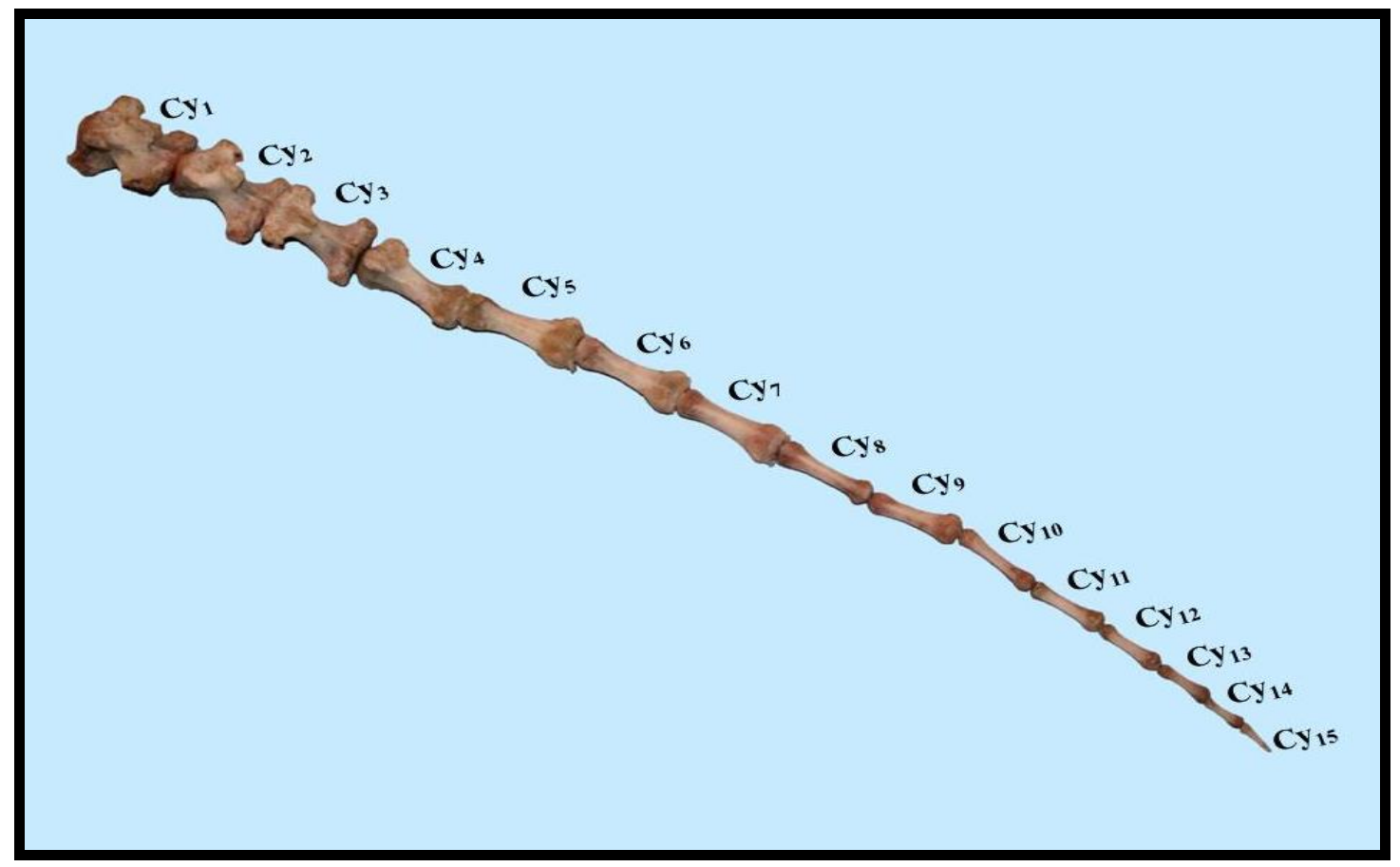

Fig.2 Dorsal view of third coccygeal vertebra of adult female Blue bull (Boselaphus tragocamelus) showing a) Anterior surface of body, b) Anterior non-articular process, c) Pedicle, d) Dorsal supraspinous process, e) Transverse process, f) Anterior surface of body, g) Groove, h) Laminae and i) Vertebral foramen

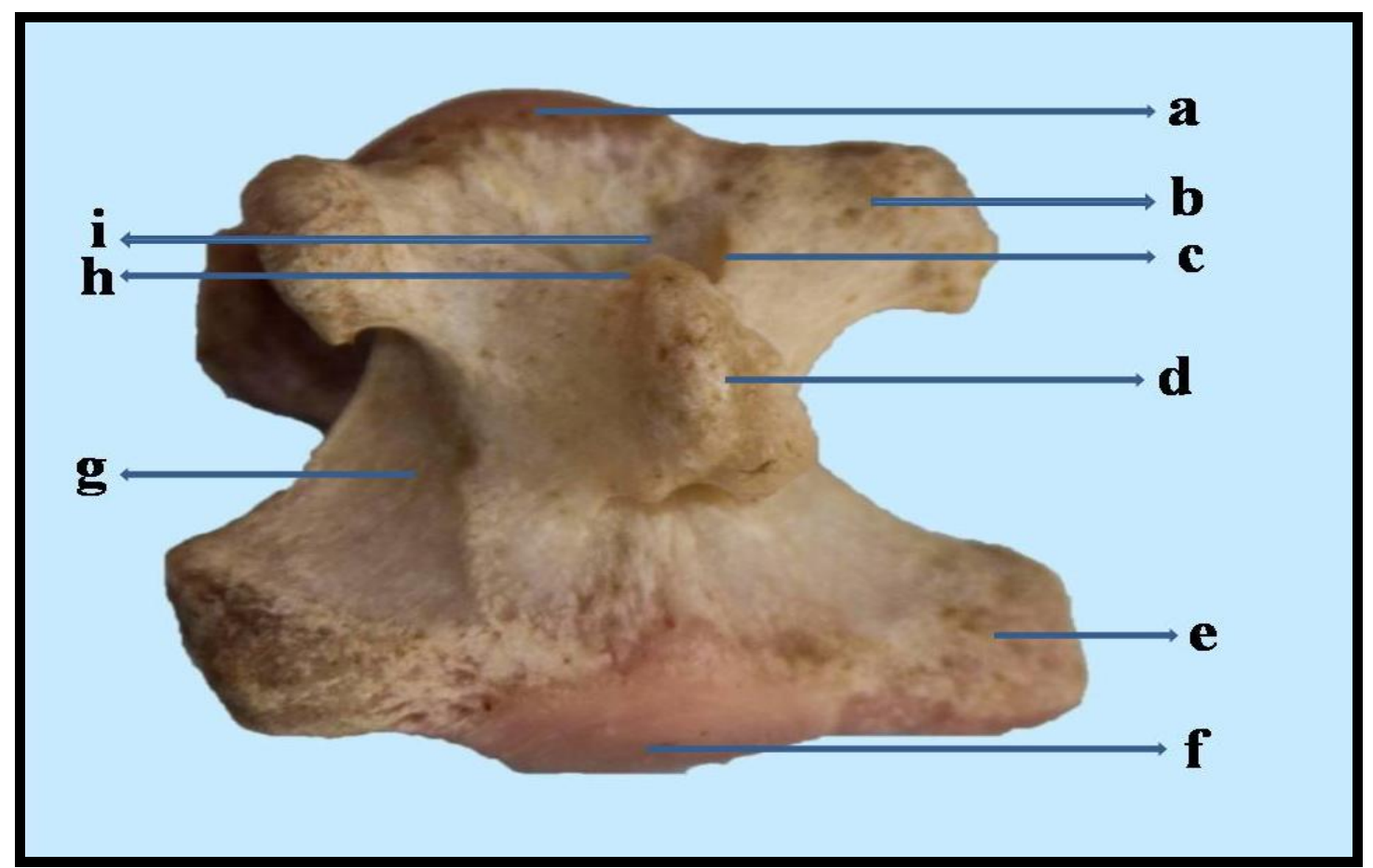


Fig.3 Ventral view of third coccygeal vertebra of adult female Blue bull (Boselaphus tragocamelus) showing a) Cranial non-articular process, b) Ventral spines, c) Anterior surface of body, d) Groove, e) Posterior surface of body, f) Ventral foramen, g) Sulcus vasculosus and h)

Transverse process

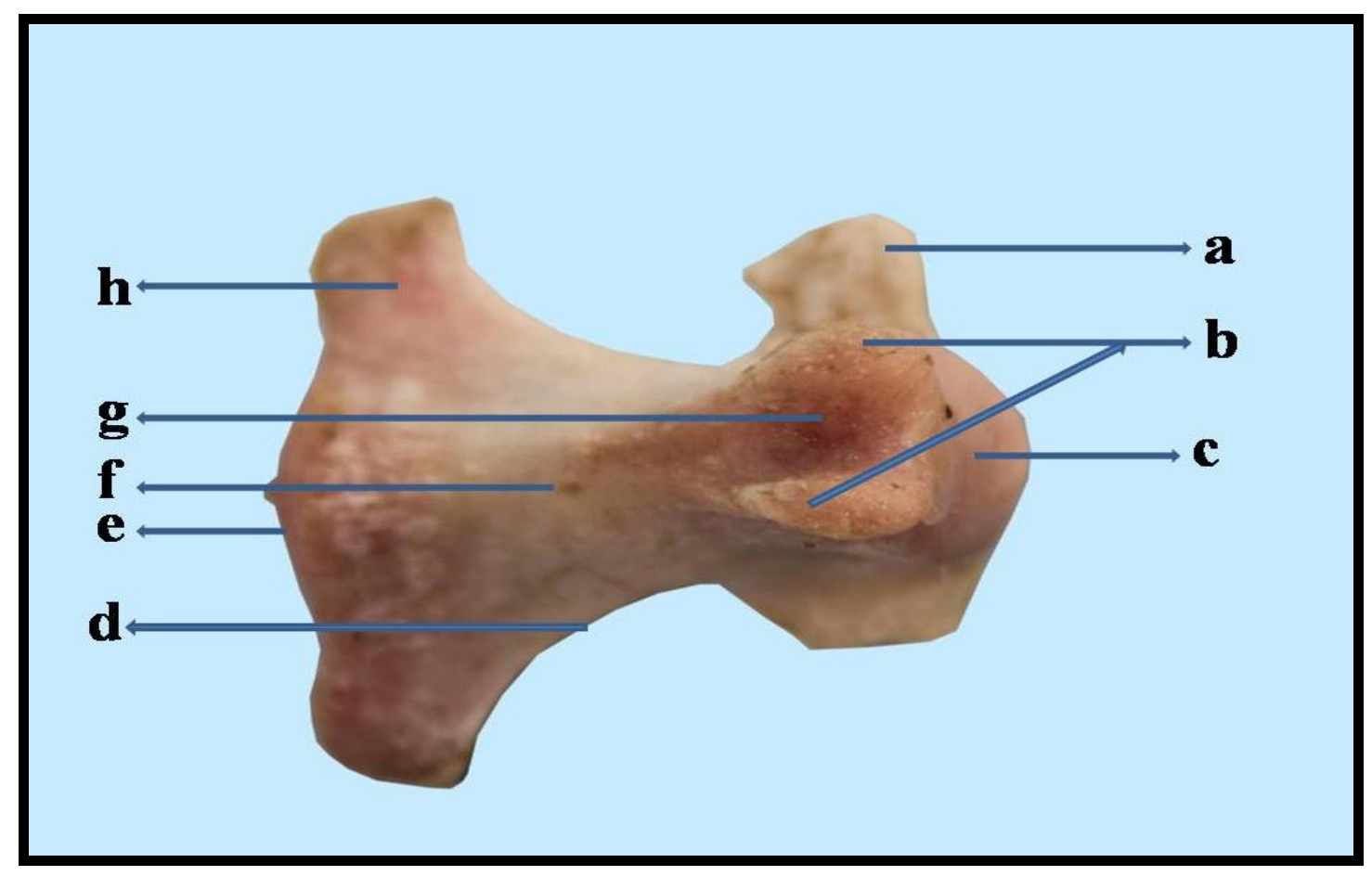

Fig.4 Ventral view of coccygeal vertebrae $\left(\mathrm{Cy}_{2}-\mathrm{Cy}_{4}\right)$ of adult male Blue bull (Boselaphus tragocamelus)

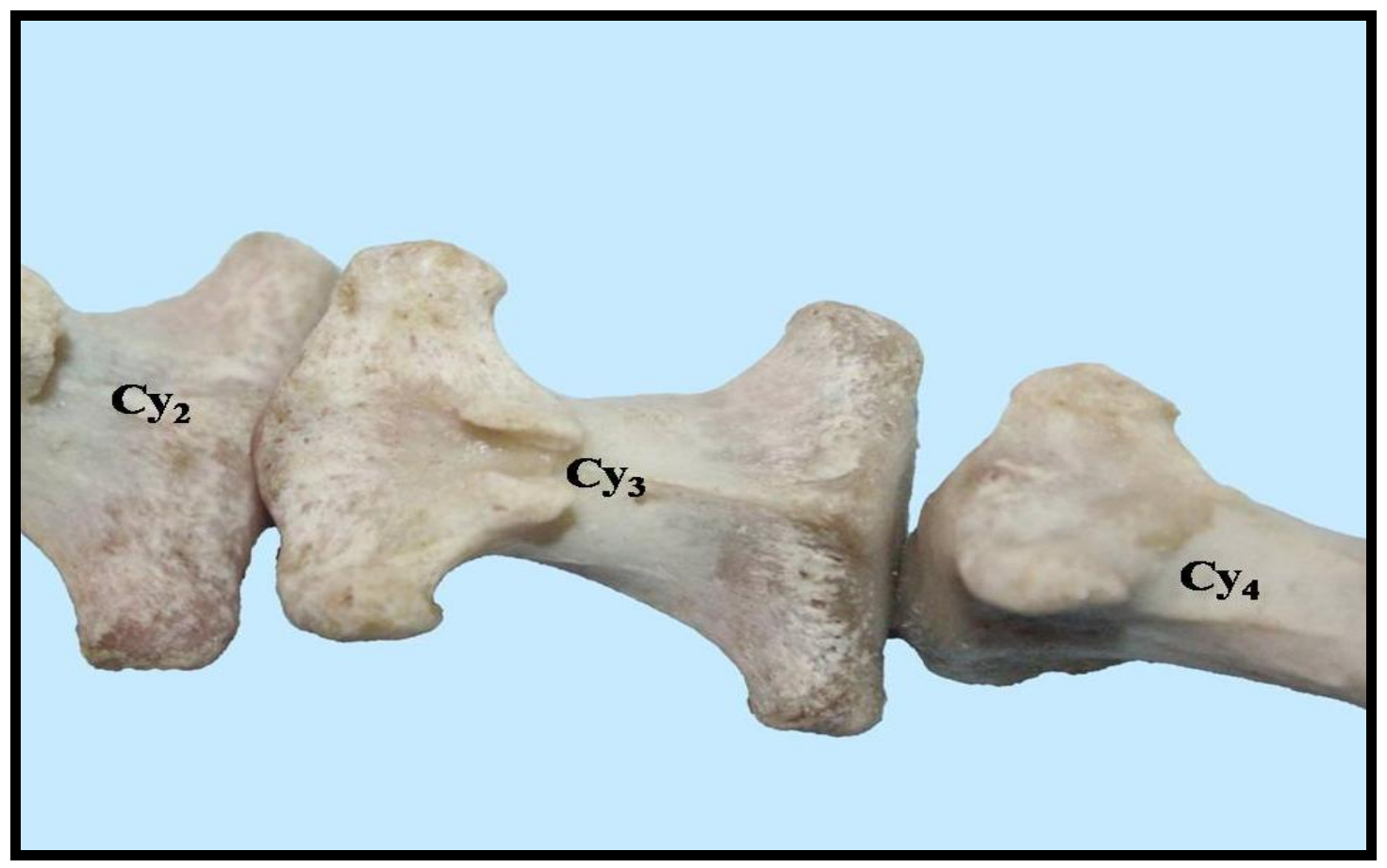


Fig.5 Ventro-lateral view of fifteenth coccygeal vertebra of adult male Blue bull (Boselaphus tragocamelus) showing a) Groove, b) Posterior surface of body, c) Ventral tubercle, d) Anterior surface of body and e) Dorsal tubercle

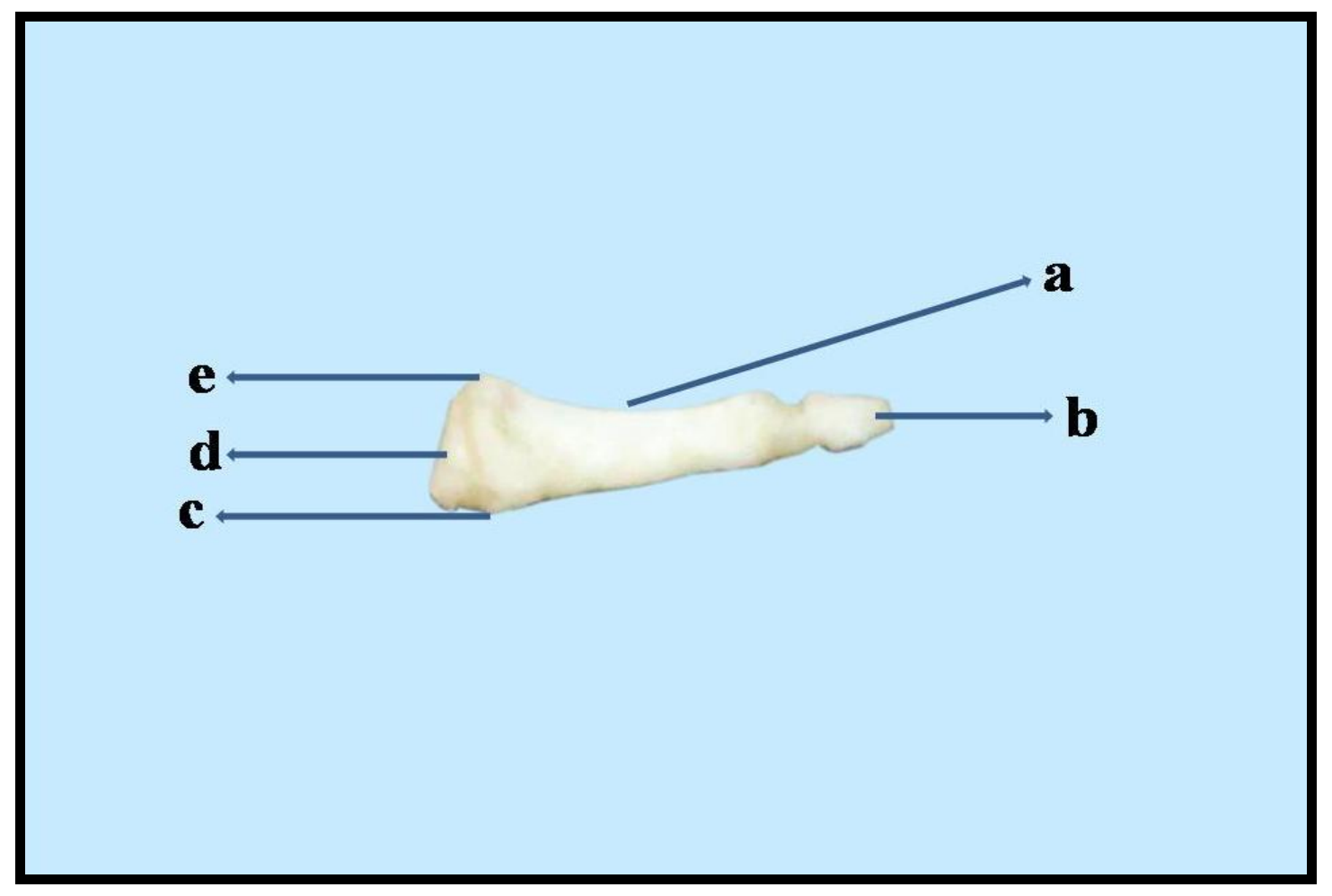

The average length of the body of $\mathrm{Cy}_{12}$ was found to be $2.62 \pm 0.06 \mathrm{~cm}$ in adult Blue bull. Further, it was measured as $2.57 \pm 0.09 \mathrm{~cm}$ and $2.67 \pm 0.09 \mathrm{~cm}$ in females and males respectively. The average length of the body of $\mathrm{Cy}_{13}$ was found to be $2.10 \pm 0.07 \mathrm{~cm}$ in adult Blue bull. Further, it was measured as $1.97 \pm 0.03 \mathrm{~cm}$ in females that was significantly lesser $(\mathrm{P}<0.05)$ than that of males, where it was found to be $2.23 \pm 0.09$ $\mathrm{cm}$. Similarly, the average length of the body of $\mathrm{Cy}_{14}$ was found to be $1.60 \pm 0.07 \mathrm{~cm}$ in adult Blue bull. Further, it was measured as $1.47 \pm 0.09 \mathrm{~cm}$ in females that was significantly lesser $(\mathrm{P}<0.05)$ than that of males, where it was found to be $1.73 \pm 0.03$ $\mathrm{cm}$. The average length of the body of $\mathrm{Cy}_{15}$ was found to be $1.20 \pm 0.06 \mathrm{~cm}$ in adult Blue bull. Further, it was measured as $1.10 \pm 0.06$ $\mathrm{cm}$ and $1.30 \pm 0.06 \mathrm{~cm}$ in females and males respectively.
The average length of dorsal spine of $\mathrm{Cy}_{4}$ was found to be $0.32 \pm 0.03 \mathrm{~cm}$ in adult Blue bull. Further, it was measured as $0.27 \pm 0.03 \mathrm{~cm}$ in females that was significantly lesser $(\mathrm{P}<0.05)$ than that of males, where it was found to be $0.37 \pm 0.01 \mathrm{~cm}$. The average thickness of dorsal spine of $\mathrm{Cy}_{4}$ at the cranial aspect was found to be $0.07 \pm 0.01 \mathrm{~cm}$ in adult Blue bull. Further, it was measured as $0.05 \pm 0.01 \mathrm{~cm}$ and $0.09 \pm 0.01 \mathrm{~cm}$ in females and males respectively. The average thickness of dorsal spine of $\mathrm{Cy}_{4}$ at the middle was found to be $0.07 \pm 0.01 \mathrm{~cm}$ in adult Blue bull. Further, it was measured as $0.05 \pm 0.01 \mathrm{~cm}$ in females that was significantly lesser $(\mathrm{P}<0.05)$ than that of males, where it was found to be $0.09 \pm 0.01$ $\mathrm{cm}$. The average thickness of dorsal spine of $\mathrm{Cy} 4$ at the caudal aspect was found to be $0.06 \pm 0.01 \mathrm{~cm}$ in adult Blue bull. Further, it was measured as $0.05 \pm 0.01 \mathrm{~cm}$ and $0.06 \pm 0.01$ $\mathrm{cm}$ in females and males respectively. The 
average height of dorsal spine of $\mathrm{Cy}_{4}$ at the cranial aspect was found to be $0.14 \pm 0.01 \mathrm{~cm}$ in adult Blue bull. Further, it was measured as $0.11 \pm 0.01 \mathrm{~cm}$ and $0.16 \pm 0.01 \mathrm{~cm}$ in females and males respectively. Similarly, the average height of dorsal spine of $\mathrm{Cy}_{4}$ at the middle was found to be $0.25 \pm 0.01 \mathrm{~cm}$ in adult Blue bull. Further, it was measured as $0.22 \pm 0.02$ $\mathrm{cm}$ and $0.27 \pm 0.01 \mathrm{~cm}$ in females and males respectively. The average height of dorsal spine of $\mathrm{Cy}_{4}$ at the caudal aspect was found to be $0.15 \pm 0.01 \mathrm{~cm}$ in adult Blue bull. Further, it was measured as $0.14 \pm 0.02 \mathrm{~cm}$ and $0.16 \pm 0.02$ $\mathrm{cm}$ in females and males respectively.

The average length of transverse process of $\mathrm{Cy}_{4}$ was found to be $0.81 \pm 0.02 \mathrm{~cm}$ in adult Blue bull. Further, it was measured as $0.75 \pm 0.02 \mathrm{~cm}$ in females that was significantly lesser $(\mathrm{P}<0.05)$ than that of males, where it was found to be $0.86 \pm 0.02$ $\mathrm{cm}$. The average length of transverse process of $\mathrm{Cy}_{5}$ was found to be $0.67 \pm 0.02 \mathrm{~cm}$ in adult Blue bull. Further, it was measured as $0.63 \pm 0.03 \mathrm{~cm}$ and $0.71 \pm 0.03 \mathrm{~cm}$ in females and males respectively. Similarly, the average length of transverse process of $\mathrm{Cy}_{6}$ was found to be $0.84 \pm 0.03 \mathrm{~cm}$ in adult Blue bull. Further, it was measured as $0.79 \pm 0.04 \mathrm{~cm}$ and $0.89 \pm 0.02 \mathrm{~cm}$ in females and males respectively. The average length of transverse process of $\mathrm{Cy}_{7}$ was found to be $0.51 \pm 0.02 \mathrm{~cm}$ in adult Blue bull. Further, it was measured as $0.47 \pm 0.02 \mathrm{~cm}$ in females that was significantly lesser $(\mathrm{P}<0.05)$ than that of males, where it was found to be $0.55 \pm 0.01$ $\mathrm{cm}$. The average distance between the transverse processes of $\mathrm{Cy}_{4}$ and $\mathrm{Cy}_{5}$ was found to be $3.48 \pm 0.03 \mathrm{~cm}$ in adult Blue bull. Further, it was measured as $3.43 \pm 0.05 \mathrm{~cm}$ and $3.53 \pm 0.03 \mathrm{~cm}$ in females and males respectively. Similarly, the average distance between the transverse processes of $\mathrm{Cy}_{5}$ and $\mathrm{Cy}_{6}$ was found to be $3.31 \pm 0.05 \mathrm{~cm}$ in adult Blue bull. Further, it was measured as $3.27 \pm 0.08 \mathrm{~cm}$ and $3.34 \pm 0.08 \mathrm{~cm}$ in females and males respectively. The average distance between the transverse processes of $\mathrm{Cy}_{6}$ and $\mathrm{Cy}_{7}$ was found to be $2.84 \pm 0.08 \mathrm{~cm}$ in adult Blue bull. Further, it was measured as $2.81 \pm 0.12 \mathrm{~cm}$ and $2.87 \pm 0.11 \mathrm{~cm}$ in females and males respectively.

The average length of cranial non-articular process of $\mathrm{Cy}_{4}$ was found to be $1.11 \pm 0.01 \mathrm{~cm}$ in adult Blue bull. Further, it was measured as $1.08 \pm 0.02 \mathrm{~cm}$ in females that was significantly lesser $(\mathrm{P}<0.05)$ than that of males, where it was found to be $1.13 \pm 0.01$ $\mathrm{cm}$. The average length of cranial nonarticular process of $\mathrm{Cy}_{5}$ was found to be $0.85 \pm 0.02 \mathrm{~cm}$ in adult Blue bull. Further, it was measured as $0.83 \pm 0.03 \mathrm{~cm}$ and $0.88 \pm 0.03$ $\mathrm{cm}$ in females and males respectively. The average width of cranial non-articular process at the cranial aspect of $\mathrm{Cy}_{4}$ was found to be $0.39 \pm 0.02 \mathrm{~cm}$ in adult Blue bull. Further, it was measured as $0.36 \pm 0.03 \mathrm{~cm}$ and $0.41 \pm 0.04$ $\mathrm{cm}$ in females and males respectively. Similarly, the average width of cranial nonarticular process at the cranial aspect of $\mathrm{Cy}_{5}$ was found to be $0.39 \pm 0.02 \mathrm{~cm}$ in adult Blue bull. Further, it was measured as $0.36 \pm 0.02$ $\mathrm{cm}$ and $0.42 \pm 0.03 \mathrm{~cm}$ in females and males respectively. The average width of cranial non-articular process at the middle of $\mathrm{Cy}_{4}$ was found to be $0.45 \pm 0.02 \mathrm{~cm}$ in adult Blue bull. Further, it was measured as $0.42 \pm 0.03 \mathrm{~cm}$ and $0.48 \pm 0.04 \mathrm{~cm}$ in females and males respectively. Similarly, the average width of cranial non-articular process at the middle of $\mathrm{Cy}_{5}$ was found to be $0.52 \pm 0.02 \mathrm{~cm}$ in adult Blue bull. Further, it was measured as $0.49 \pm 0.02 \mathrm{~cm}$ and $0.55 \pm 0.03 \mathrm{~cm}$ in females and males respectively.

The average width of cranial non-articular process at the caudal aspect of $\mathrm{Cy}_{4}$ was found to be $0.31 \pm 0.02 \mathrm{~cm}$ in adult Blue bull. Further, it was measured as $0.28 \pm 0.03 \mathrm{~cm}$ and $0.35 \pm 0.03 \mathrm{~cm}$ in females and males respectively. Similarly, the average width of 
cranial non-articular process at the caudal aspect of $\mathrm{Cy}_{5}$ was found to be $0.32 \pm 0.01 \mathrm{~cm}$ in adult Blue bull. Further, it was measured as $0.30 \pm 0.01 \mathrm{~cm}$ and $0.35 \pm 0.01 \mathrm{~cm}$ in females and males respectively. The average distance between the cranial non-articular process of $\mathrm{Cy}_{4}$ and $\mathrm{Cy}_{5}$ was found to be $3.17 \pm 0.04 \mathrm{~cm}$ in adult Blue bull. Further, it was measured as $3.14 \pm 0.05 \mathrm{~cm}$ and $3.20 \pm 0.06 \mathrm{~cm}$ in females and males respectively.

The average minimum distance between the two cranial non-articular processes of $\mathrm{Cy}_{4}$ was found to be $0.97 \pm 0.02 \mathrm{~cm}$ in adult Blue bull. Further, it was measured as $0.94 \pm 0.03$ $\mathrm{cm}$ and $1.00 \pm 0.01 \mathrm{~cm}$ in females and males respectively. The average minimum distance between the two cranial non-articular processes of $\mathrm{Cy}_{5}$ was found to be $0.35 \pm 0.02$ $\mathrm{cm}$ in adult Blue bull. Further, it was measured as $0.31 \pm 0.02 \mathrm{~cm}$ in females that was significantly lesser $(\mathrm{P}<0.05)$ than that of males, where it was found to be $0.39 \pm 0.01$ $\mathrm{cm}$. The average distance between the cranial non-articular process and transverse process of $\mathrm{Cy}_{4}$ was found to be $1.91 \pm 0.07 \mathrm{~cm}$ in adult Blue bull. Further, it was measured as $1.86 \pm 0.10 \mathrm{~cm}$ and $1.95 \pm 0.10 \mathrm{~cm}$ in females and males respectively. The average distance between the cranial non-articular process and transverse process of $\mathrm{Cy}_{5}$ was found to be $2.24 \pm 0.02 \mathrm{~cm}$ in adult Blue bull. Further, it was measured as $2.20 \pm 0.02 \mathrm{~cm}$ in females that was significantly lesser $(\mathrm{P}<0.05)$ than that of males, where it was found to be $2.29 \pm 0.02$ $\mathrm{cm}$.

The average length of ventral spine of $\mathrm{Cy}_{4}$ was found to be $0.99 \pm 0.02 \mathrm{~cm}$ in adult Blue bull. Further, it was measured as $0.95 \pm 0.04$ $\mathrm{cm}$ and $1.03 \pm 0.02 \mathrm{~cm}$ in females and males respectively. The average length of ventral spine of $\mathrm{Cy}_{5}$ was found to be $1.16 \pm 0.01 \mathrm{~cm}$ in adult Blue bull. Further, it was measured as $1.12 \pm 0.01 \mathrm{~cm}$ in females that was significantly lesser $(\mathrm{P}<0.05)$ than that of males, where it was found to be $1.19 \pm 0.01$ $\mathrm{cm}$. The average length of ventral spine of $\mathrm{Cy}_{6}$ was found to be $1.20 \pm 0.02 \mathrm{~cm}$ in adult Blue bull. Further, it was measured as $1.18 \pm 0.02 \mathrm{~cm}$ and $1.23 \pm 0.02 \mathrm{~cm}$ in females and males respectively. Similarly, the average length of ventral spine of $\mathrm{Cy}_{7}$ was found to be $0.73 \pm 0.03 \mathrm{~cm}$ in adult Blue bull. Further, it was measured as $0.71 \pm 0.04 \mathrm{~cm}$ and $0.76 \pm 0.03$ $\mathrm{cm}$ in females and males respectively.

The average height of ventral spine at the cranial aspect of $\mathrm{Cy}_{4}$ was found to be $0.34 \pm 0.01 \mathrm{~cm}$ in adult Blue bull. Further, it was measured as $0.32 \pm 0.01 \mathrm{~cm}$ in females that was significantly lesser $(\mathrm{P}<0.05)$ than that of males, where it was found to be $0.36 \pm 0.01$ $\mathrm{cm}$. The average height of ventral spine at the cranial aspect of $\mathrm{Cy}_{5}$ was found to be $0.41 \pm 0.02 \mathrm{~cm}$ in adult Blue bull. Further, it was measured as $0.38 \pm 0.03 \mathrm{~cm}$ and $0.44 \pm 0.03$ $\mathrm{cm}$ in females and males respectively. The average height of ventral spine at the cranial aspect of $\mathrm{Cy}_{6}$ was found to be $0.37 \pm 0.01 \mathrm{~cm}$ in adult Blue bull. Further, it was measured as $0.35 \pm 0.01 \mathrm{~cm}$ in females that was significantly lesser $(\mathrm{P}<0.05)$ than that of males, where it was found to be $0.39 \pm 0.01$ $\mathrm{cm}$. Similarly, the average height of ventral spine at the cranial aspect of $\mathrm{Cy}_{7}$ was found to be $0.22 \pm 0.01 \mathrm{~cm}$ in adult Blue bull. Further, it was measured as $0.20 \pm 0.01 \mathrm{~cm}$ in females that was significantly lesser $(\mathrm{P}<0.05)$ than that of males, where it was found to be $0.24 \pm 0.01$ $\mathrm{cm}$.

The average height of ventral spine at the middle of $\mathrm{Cy}_{4}$ was found to be $0.43 \pm 0.01 \mathrm{~cm}$ in adult Blue bull. Further, it was measured as $0.40 \pm 0.01 \mathrm{~cm}$ in females that was significantly lesser $(\mathrm{P}<0.05)$ than that of males, where it was found to be $0.46 \pm 0.01$ $\mathrm{cm}$. The average height of ventral spine at the middle of $\mathrm{Cy}_{5}$ was found to be $0.49 \pm 0.02 \mathrm{~cm}$ in adult Blue bull. Further, it was measured as $0.47 \pm 0.01 \mathrm{~cm}$ and $0.52 \pm 0.03 \mathrm{~cm}$ in females 
and males respectively. Similarly, the average height of ventral spine at the cranial aspect of $\mathrm{Cy}_{6}$ was found to be $0.40 \pm 0.02 \mathrm{~cm}$ in adult Blue bull. Further, it was measured as $0.38 \pm 0.02 \mathrm{~cm}$ and $0.43 \pm 0.02 \mathrm{~cm}$ in females and males respectively. The average height of ventral spine at the middle of $\mathrm{Cy}_{7}$ was found to be $0.33 \pm 0.01 \mathrm{~cm}$ in adult Blue bull. Further, it was measured as $0.30 \pm 0.01 \mathrm{~cm}$ in females that was significantly lesser $(\mathrm{P}<0.05)$ than that of males, where it was found to be $0.35 \pm 0.01 \mathrm{~cm}$. The average height of ventral spine at the caudal aspect of $\mathrm{Cy}_{4}$ was found to be $0.42 \pm 0.01 \mathrm{~cm}$ in adult Blue bull. Further, it was measured as $0.40 \pm 0.01 \mathrm{~cm}$ in females that was significantly lesser $(\mathrm{P}<0.05)$ than that of males, where it was found to be $0.44 \pm 0.01$ $\mathrm{cm}$. Similarly, the average height of ventral spine at the caudal aspect of $\mathrm{Cy}_{5}$ was found to be $0.38 \pm 0.02 \mathrm{~cm}$ in adult Blue bull. Further, it was measured as $0.35 \pm 0.02 \mathrm{~cm}$ in females that was significantly lesser $(\mathrm{P}<0.05)$ than that of males, where it was found to be $0.42 \pm 0.02$ $\mathrm{cm}$. The average height of ventral spine at the cranial aspect of $\mathrm{Cy}_{6}$ was found to be $0.38 \pm 0.01 \mathrm{~cm}$ in adult Blue bull. Further, it was measured as $0.36 \pm 0.01 \mathrm{~cm}$ and $0.40 \pm 0.02$ $\mathrm{cm}$ in females and males respectively. Similarly, the average height of ventral spine at the cranial aspect of $\mathrm{Cy}_{7}$ was found to be $0.21 \pm 0.01 \mathrm{~cm}$ in adult Blue bull. Further, it was measured as $0.20 \pm 0.01 \mathrm{~cm}$ and $0.23 \pm 0.01$ $\mathrm{cm}$ in females and males respectively.

The average distance between the ventral spines of $\mathrm{Cy}_{4}$ and $\mathrm{Cy}_{5}$ was found to be $3.17 \pm 0.02 \mathrm{~cm}$ in adult Blue bull. Further, it was measured as $3.14 \pm 0.02 \mathrm{~cm}$ and $3.21 \pm 0.02$ $\mathrm{cm}$ in females and males respectively. Similarly, the average distance between the ventral spines of $\mathrm{Cy}_{5}$ and $\mathrm{Cy}_{6}$ was found to be $3.21 \pm 0.02 \mathrm{~cm}$ in adult Blue bull. Further, it was measured as $3.17 \pm 0.03 \mathrm{~cm}$ and $3.25 \pm 0.03$ $\mathrm{cm}$ in females and males respectively. The average distance between the ventral spines of $\mathrm{Cy}_{6}$ and $\mathrm{Cy}_{7}$ was found to be $3.21 \pm 0.04 \mathrm{~cm}$ in adult Blue bull. Further, it was measured as $3.16 \pm 0.04 \mathrm{~cm}$ and $3.26 \pm 0.05 \mathrm{~cm}$ in females and males respectively. The average length of sulcus vasculosus of $\mathrm{Cy}_{4}$ was found to be $0.79 \pm 0.04 \mathrm{~cm}$ in adult Blue bull (Diagram $51)$. Further, it was measured as $0.73 \pm 0.05 \mathrm{~cm}$ and $0.85 \pm 0.04 \mathrm{~cm}$ in females and males respectively. The average length of sulcus vasculosus of $\mathrm{Cy}_{5}$ was found to be $0.66 \pm 0.02$ $\mathrm{cm}$ in adult Blue bull. Further, it was measured as $0.62 \pm 0.02 \mathrm{~cm}$ in females that was significantly lesser $(\mathrm{P}<0.05)$ than that of males, where it was found to be $0.69 \pm 0.01$ $\mathrm{cm}$. Similarly, the average length of sulcus vasculosus of $\mathrm{Cy}_{6}$ was found to be $1.06 \pm 0.02$ $\mathrm{cm}$ in adult Blue bull. Further, it was measured as $1.03 \pm 0.02 \mathrm{~cm}$ in females that was significantly lesser $(\mathrm{P}<0.05)$ than that of males, where it was found to be $1.09 \pm 0.01$ $\mathrm{cm}$. The average length of sulcus vasculosus of $\mathrm{Cy}_{7}$ was found to be $0.64 \pm 0.01 \mathrm{~cm}$ in adult Blue bull. Further, it was measured as $0.62 \pm 0.02 \mathrm{~cm}$ and $0.65 \pm 0.02 \mathrm{~cm}$ in females and males respectively.

The average width of sulcus vasculosus of $\mathrm{Cy}_{4}$ at the cranial aspect was found to be $0.36 \pm 0.02 \mathrm{~cm}$ in adult Blue bull. Further, it was measured as $0.34 \pm 0.03 \mathrm{~cm}$ and $0.38 \pm 0.04$ $\mathrm{cm}$ in females and males respectively. The average width of sulcus vasculosus of $\mathrm{Cy}_{5}$ at the cranial aspect was found to be $0.21 \pm 0.01$ $\mathrm{cm}$ in adult Blue bull. Further, it was measured as $0.19 \pm 0.01 \mathrm{~cm}$ in females that was significantly lesser $(\mathrm{P}<0.05)$ than that of males, where it was found to be $0.23 \pm 0.01$ $\mathrm{cm}$. The average width of sulcus vasculosus of $\mathrm{Cy}_{6}$ at the cranial aspect was found to be $0.23 \pm 0.01 \mathrm{~cm}$ in adult Blue bull.

Further, it was measured as $0.20 \pm 0.01 \mathrm{~cm}$ and $0.25 \pm 0.02 \mathrm{~cm}$ in females and males respectively. The average width of sulcus vasculosus of $\mathrm{Cy}_{7}$ at the cranial aspect was found to be $0.08 \pm 0.02 \mathrm{~cm}$ in adult Blue bull. Further, it was measured as $0.06 \pm 0.01 \mathrm{~cm}$ in 
females that was significantly lesser $(\mathrm{P}<0.05)$ than that of males, where it was found to be $0.09 \pm 0.01 \mathrm{~cm}$.

The average width of sulcus vasculosus of $\mathrm{Cy}_{4}$ at the middle was found to be $0.31 \pm 0.01$ $\mathrm{cm}$ in adult Blue bull. Further, it was measured as $0.29 \pm 0.01 \mathrm{~cm}$ and $0.33 \pm 0.01 \mathrm{~cm}$ in females and males respectively. Similarly, the average width of sulcus vasculosus of $\mathrm{Cy}_{5}$ at the middle was found to be $0.13 \pm 0.01 \mathrm{~cm}$ in adult Blue bull. Further, it was measured as $0.12 \pm 0.01 \mathrm{~cm}$ and $0.14 \pm 0.02 \mathrm{~cm}$ in females and males respectively. The average width of sulcus vasculosus of $\mathrm{Cy}_{6}$ at the middle was found to be $0.11 \pm 0.01 \mathrm{~cm}$ in adult Blue bull. Further, it was measured as $0.09 \pm 0.01 \mathrm{~cm}$ in females that was significantly lesser $(\mathrm{P}<0.05)$ than that of males, where it was found to be $0.13 \pm 0.01 \mathrm{~cm}$. The average width of sulcus vasculosus of $\mathrm{Cy}_{7}$ at the middle aspect was found to be $0.05 \pm 0.01 \mathrm{~cm}$ in adult Blue bull. Further, it was measured as $0.04 \pm 0.01 \mathrm{~cm}$ and $0.06 \pm 0.01 \mathrm{~cm}$ in females and males respectively.

The average width of sulcus vasculosus of $\mathrm{Cy}_{4}$ at the caudal aspect was found to be $0.15 \pm 0.01 \mathrm{~cm}$ in adult Blue bull. Further, it was measured as $0.13 \pm 0.01 \mathrm{~cm}$ and $0.17 \pm 0.01$ $\mathrm{cm}$ in females and males respectively. Similarly, the average width of sulcus vasculosus of $\mathrm{Cy}_{5}$ at the caudal aspect was found to be $0.09 \pm 0.01 \mathrm{~cm}$ in adult Blue bull. Further, it was measured as $0.07 \pm 0.01 \mathrm{~cm}$ and $0.11 \pm 0.01 \mathrm{~cm}$ in females and males respectively. The average width of sulcus vasculosus of $\mathrm{Cy}_{6}$ at the caudal aspect was found to be $0.06 \pm 0.01 \mathrm{~cm}$ in adult Blue bull. Further, it was measured as $0.04 \pm 0.001 \mathrm{~cm}$ and $0.07 \pm 0.01 \mathrm{~cm}$ in females and males respectively. Similarly, the average width of sulcus vasculosus of $\mathrm{Cy}_{7}$ at the middle aspect was found to be $0.05 \pm 0.01 \mathrm{~cm}$ in adult Blue bull. Further, it was measured as $0.04 \pm 0.01$ $\mathrm{cm}$ and $0.05 \pm 0.01 \mathrm{~cm}$ in females and males respectively. The average distance between the sulcus vasculosus of $\mathrm{Cy}_{4}$ and $\mathrm{Cy}_{5}$ was found to be $3.10 \pm 0.07 \mathrm{~cm}$ in adult Blue bull. Further, it was measured as $3.00 \pm 0.06 \mathrm{~cm}$ and $3.20 \pm 0.12 \mathrm{~cm}$ in females and males respectively. Similarly, the average distance between the sulcus vasculosus of $\mathrm{Cy}_{5}$ and $\mathrm{Cy}_{6}$ was found to be $3.10 \pm 0.06 \mathrm{~cm}$ in adult Blue bull. Further, it was measured as $3.00 \pm 0.06$ $\mathrm{cm}$ and $3.20 \pm 0.06 \mathrm{~cm}$ in females and males respectively. The average distance between the sulcus vasculosus of $\mathrm{Cy}_{6}$ and $\mathrm{Cy}_{7}$ was found to be $3.05 \pm 0.07 \mathrm{~cm}$ in adult Blue bull. Further, it was measured as $2.97 \pm 0.09 \mathrm{~cm}$ and $3.13 \pm 0.09 \mathrm{~cm}$ in females and males respectively (Table 2 ).

The arches, dorsal spine, ventral spine, transverse process and cranial non-articular process were found in $\mathrm{Cy}_{3}-\mathrm{Cy}_{6}$ in Blue bull and there after they reduced in both the sexes. The fifteenth coccygeal vertebra was represented by cylindrical body with reduced processes. Further, various parameters of the third to fifteenth coccygeal vertebrae like average length and width of body, average length, height and thickness of dorsal spine, average length and width of transverse process, cranial non-articular process and sulcus vasculosus, average length and height of ventral spine, average length of vertebral canal, average cranial and caudal diameters of vertebral canal showed characteristic sexual variations in the Blue bull.

There is no previous information on these parameters in the third to fifteenth coccygeal vertebrae of Blue bull, nor in any other domestic animals with which comparisons could be made. We therefore believe that the data presented above would form a baseline for further work especially comparability and compatibility are now desirable traits as efforts are geared up towards massive improvement in the livestock sector of the international economy. 


\section{Acknowledgements}

The authors are grateful to the Dean, CVASc., GBPUA\&T, Pantngar, Uttarakhand and Ministry of Environment of Forests (MoEF), New Delhi and Jodhpur Zoo, Rajasthan, India for providing facilities and support for carrying out research on the bones of Blue bull. Funding was provided by Department of Science and Technology, New Delhi and Indian Council of Agricultural research, New Delhi, India as Ph.D. grant (DST-INSPIRE Fellowship and ICAR-SRF (PGS)) to the first author.

\section{References}

Bagchi, S., Goyal, S.P. and Shankar, K. 2004. Herbivore density and biomass in a semi-arid tropical dry deciduous forest of western India. Journal of Tropical Ecology. 20(4): 475-478.

Breland, O.P. 1943. Manual of comparative anatomy, Mcgraw- Hill Book Company.Inc, New York and London, pp 146-151.

Dyce, K.M., Sack, W.O. and Wensing C.J.G. 2006. Text Book of Veterinary Anatomy, Saunders Elsevier, $4^{\text {th }}$ ed., pp $35-41$.

Frandson, B.S. and Spurgeon, T.L. 1992. Anatomy and physiology of farm animals. Lea and Febiger, Philadelphia. $5^{\text {th }}$ ed. pp 64-68.

Getty, R., Sisson, S. and Grossman, J.D. 1930. The Anatomy of the Domestic Animals. W.B. Saunders Comp., Philadelphia. 2nd ed. (Vol. 1), pp 25-27, 33-45,125-130.

Konig, H.E. and Liebich, H.G. 2005. Veterinary Anatomy of Domestic Animals, 3rd Edn, Schattauer, Stuttgart, Germany. pp 49-104, 145-160, 215-236.

Levine, J.M., Levine, G.J., Hoffman, A.G., Mez, J. and Bratton, G.R. 2007. Comparative Anatomy of the Horse, Ox and Dog: The Vertebral Column and Peripheral Nerves. CE article-1, pp 279281.

Meena, V. K. 2012. Gross studies on the bones of vertebral column in chital (Axis axis). Masters' thesis submitted to the Rajasthan University of Veterinary and Animal Sciences, Bikaner.

Miller, M.E., Christensen, G.C. and Evans, H.E. 1964. Anatomy of the Dog. WB Saunders Company, Philadelphia, USA, pp 51-61.

Ozkan, Z.E. 2007. Macro-anatomical investigations on the skeletons of Molerat (Spalax leucodon nordmann) III. Skeleton axiale. Vet. Archiv., 77: 281289.

Raghavan, D. 1964. Anatomy of Ox. Indian Council of Agricultural Research, New Delhi, pp 17-38.

Rajani, C.V. and Chungath, J.J. 2012. Studies on the Lumbar, Sacral and Coccygeal Vertebrae of Indian Muntjac (Muntiacus muntjak). Indian Journal of Veterinary Anatomy. 24 (2): 78-79.

Sathapathy, S., Dhote, B.S., Singh, I., Mahanta, D. and Tamil selvan, S. 2017. Gross and morphometrical studies on the sacrum of blue bull (Boselaphus tragocamelus). Journal of Entomology and Zoology Studies. 5(6): 1591-1597.

Sathapathy, S., B.S. Dhote, M. Mrigesh, D. Mahanta and Tamil Selvan, S. 2018a. Gross and Morphometrical Studies on the Sternum of Blue Bull (Boselaphus tragocamelus). Int. J. Curr. Microbiol. App. Sci. 7(01): 136-145. doi: https://doi.org/10.20546/ijcmas.2018.70 1.015

Sathapathy, S., Dhote, B.S., Singh, I., Mahanta, D. and Mrigesh, M. and Joshi, S. K. 2018b. Gross Anatomical and Sex wise Biometrical Studies on the Atlas and Axis of Blue bull (Boselaphus tragocamelus). Journal of Animal 
Research. 8(1): 137-147. DOI: Snedecor, G.W. and Cochran, W.G. 1994. 10.30954/2277-940X.2018.00150.22.

Sathapathy, S., Dhote, B.S., Singh, I., Mahanta, D., Tamil selvan, S. and Mrigesh, M. 2018c. Gross morphometrical study on the atypical $\left(6^{\text {th }}\right.$ and $\left.7^{\text {th }}\right)$ cervical vertebrae of Blue bull (Boselaphus tragocamelus) with special reference to sexual dimorphism. International Journal of Livestock Research. 8(9): 192-201. DOI 10.5455/ijlr.20180207043008.

Statistical Methods. 8th edn. lowa State University Press, Ames, lowa, USA.

Yilmaz, S. 1998. Macro-Anatomical investigations on the skeletons of porcupine (Hystrix cristita). Anatomia Histologia Embryoligia., 27: 293-296.

Yilmaz, S., Dinç, G. and Toprak, B. 2000. Macro-anatomical investigations on skeletons of otter (Lutra lutra) III. Skeleton axiale. Vet. Arhiv., 70: 191198.

Smuts, M.S. and Bezuidenhout, A.J. 1987. Anatomy of Dromedary, Oxford Science Publications, pp 9-20.

\section{How to cite this article:}

Sathapathy, S., B.S. Dhote, D. Mahanta, S. Tamilselvan, I. Singh, M. Mrigesh and Joshi, S.K. 2018. Gross Morphological and Sex wise Morphometrical Studies on the Third to Fifteenth Coccygeal Vertebrae of Blue Bull (Boselaphus tragocamelus). Int.J.Curr.Microbiol.App.Sci. 7(11): 411-428. doi: https://doi.org/10.20546/ijcmas.2018.711.049 